\title{
Geologic Ages and Accumulation Rates of Basalt-Flow Groups and Sedimentary Interbeds in Selected Wells at the Idaho National Engineering Laboratory, Idaho
}

U.S. Geological Survey

Water-Resources Investigations Report 97-4010
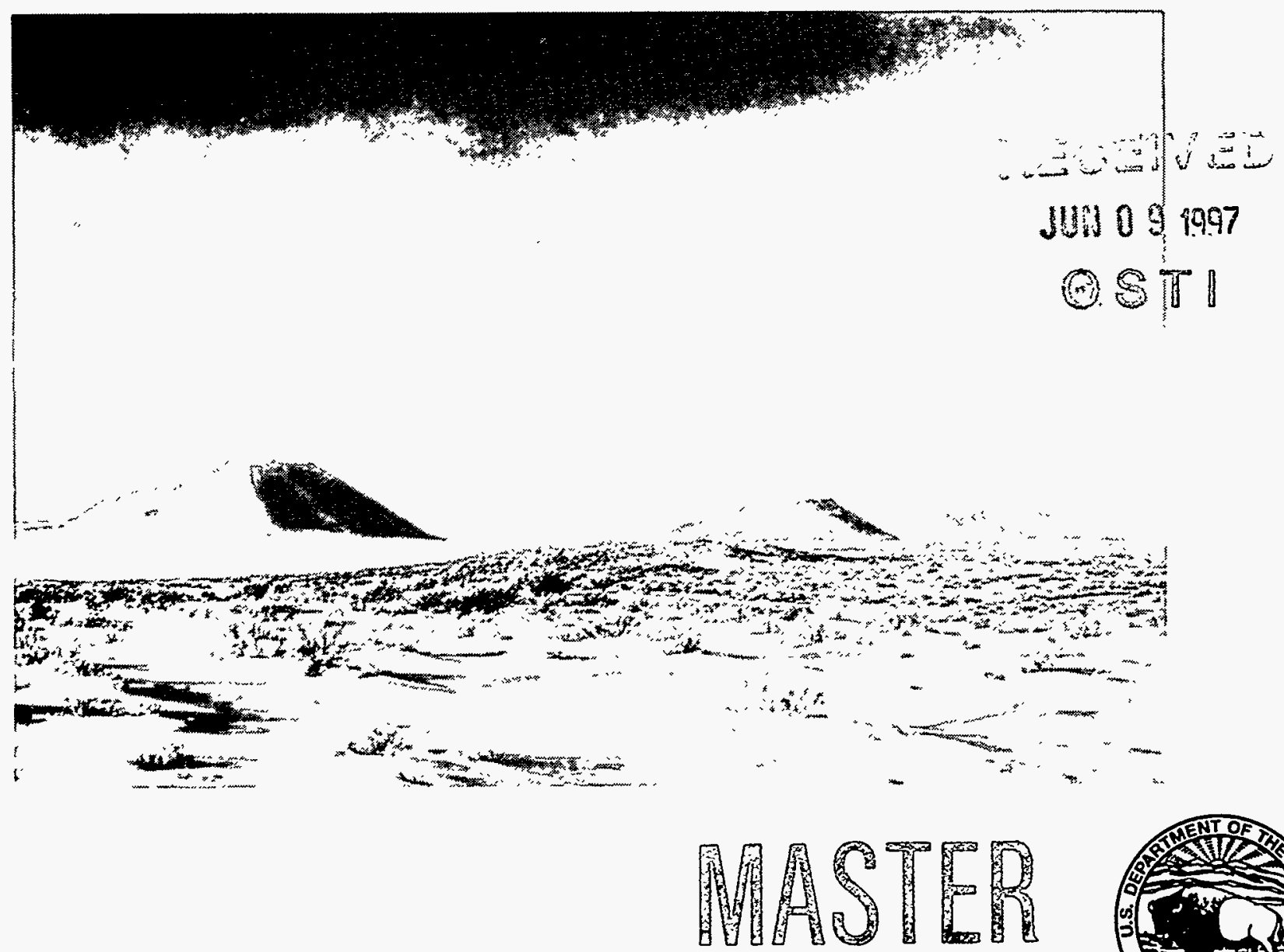

Prepared in cooperation with the U.S. DEPARTMENT OF ENERGY

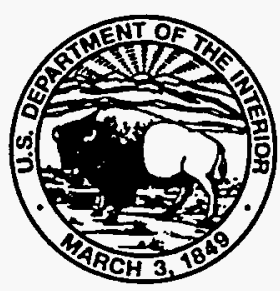




\section{Geologic Ages and Accumulation Rates of Basalt-Flow Groups and Sedimentary Interbeds in Selected Wells at the Idaho National Engineering Laboratory, Idaho}

By S.R. Anderson, Michael J. Liszewski, and L. DeWayne Cecil

U.S. GEOLOGICAL SURVEY

Water-Resources Investigations Report 97-4010

Prepared in cooperation with

U.S. DEPARTMENT OF ENERGY

Idaho Falls, Idaho

January 1997

DISTRIBUTION OF THIS DOCUMENT IS UNLIMTED 


\title{
U.S. DEPARTMENT OF THE INTERIOR \\ BRUCE BABBITT, Secretary
}

\author{
U.S. GEOLOGICAL SURVEY \\ GORDON P. EATON, Director
}

For additional information write to:

U.S. Geological Survey

INEL, MS 4148

P.O. Box 2230

Idaho Falls, ID 83403
Copies of this report can be purchased from:

U.S. Geological Survey

Branch of Information Services

Box 25286, MS 517

Denver, CO 80225-0286 


\section{DISCLAIMER}

Portions of this document may be illegible in electronic image products. Images are produced from the best available original document. 


\section{DISCLAIMER}

This report was prepared as an account of work sponsored by an agency of the United States Government. Neither the United States Government nor any agency thereof, nor any of their employees, make any warranty, express or implied, or assumes any legal liability or responsibility for the accuracy, completeness, or usefulness of any information, apparatus, product, or process disclosed, or represents that its use would not infringe privately owned rights. Reference herein to any specific commercial product, process, or service by trade name, trademark, manufacturer, or otherwise does not necessarily constitute or imply its endorsement, recommendation, or favoring by the United States Government or any agency thereof. The views and opinions of authors expressed herein do not necessarily state or reflect those of the United States Government or any agency thereof. 


\section{CONTENTS}

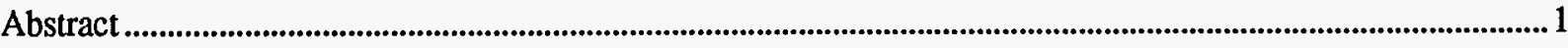

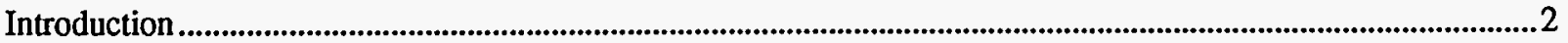

Purpose and scope ......................................................................................................................................

Acknowledgments ........................................................................................................................................

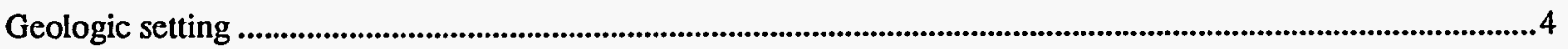

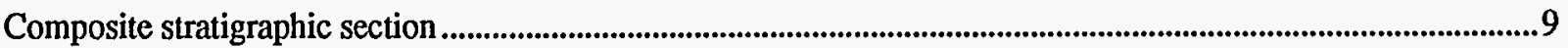

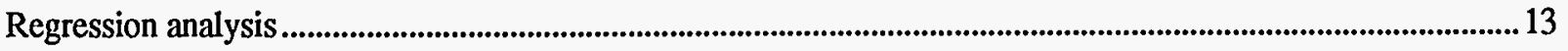

Geologic ages and accumulation rates ...................................................................................................................... 16

Geologic ages ......................................................................................................................................

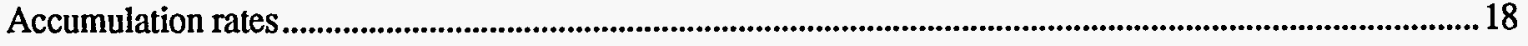

Stratigraphic and structural implications ...........................................................................................................19

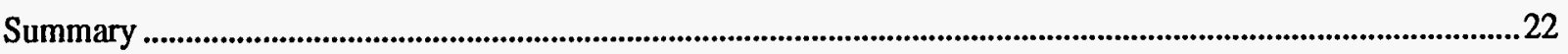

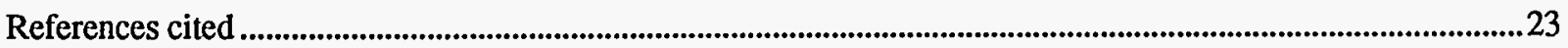

\section{FIGURES}

1. Map showing location of the Idaho National Engineering Laboratory and selected facilities ...............................3

2. Geologic section F-F' through the Radioactive Waste Management Complex, the Idaho Chemical Processing Plant, and Well NPR TEST ................................................................................................................6

3. Map showing locations of selected wells and cores used to evaluate geologic ages, accumulation rates, stratigraphy, and structure of basalt-flow groups and sedimentary interbeds in the unsaturated zone and the Snake River Plain aquifer at the Idaho National Engineering Laboratory

4. Graph showing relation between depths and measured geologic ages of basalt-flow groups DE4-5 through $I$ in well USGS 80 at the Idaho National Engineering Laboratory

5. Graph showing relation between depths and measured geologic ages of basalt-flow groups $A B$ through I in well NPR TEST at the Idaho National Engineering Laboratory

6. Graph showing relation between depths and measured geologic ages of basalt-flow groups $A B$ through $I$ in well PBF \#2 at the Idaho National Engineering Laboratory

7. Graph showing relation between cumulative depths and geologic ages of selected basalt-flow groups and sedimentary interbeds in a composite stratigraphic section of the unsaturated zone and the Snake River Plain aquifer at the Idaho National Engineering Laboratory-present to about 800 thousand years before present

8. Graph showing relation between cumulative depths and geologic ages of selected basalt-flow groups and sedimentary interbeds in a composite stratigraphic section of the unsaturated zone and the Snake River Plain aquifer at the Idaho National Engineering Laboratory-about 800 to 1,800 thousand years before present. 


\section{TABLES}

1. Selected cores and sources of data used to evaluate stratigraphic units underlying the Idaho National Engineering Laboratory.

2. Wells that penetrate the effective base of the Snake River Plain aquifer at the Idaho National Engineering Laboratory.

3. Prolonged hiatuses between basalt flows above the effective base of the Snake River Plain aquifer in selected wells at the Idaho National Engineering Laboratory

4. Sites used to construct a composite stratigraphic section of selected basalt-flow groups and sedimentary interbeds in the unsaturated zone and the Snake River Plain aquifer at the Idaho National Engineering Laboratory

5. Line segments and regressions used to estimate geologic ages and maximum accumulation/subsidence rates of selected basalt-flow groups and sedimentary interbeds in the unsaturated zone and the Snake River Plain aquifer at the Idaho National Engineering Laboratory

6. Measured and estimated geologic ages of selected basalt-flow groups and sedimentary interbeds in the unsaturated zone and the Snake River Plain aquifer at the Idaho National Engineering Laboratory

CONVERSION FACTORS AND VERTICAL DATUM

\begin{tabular}{rll}
\hline Multiply & By & To obtain \\
\hline foot $(\mathrm{ft})$ & 0.3048 & meter \\
mile (mi) & 1.6094 & kilometer \\
square mile $\left(\mathrm{mi}^{2}\right)$ & 2.590 & square kilometer \\
\hline
\end{tabular}

Sea level: In this report, "sea level" refers to the National Geodetic Vertical Datum of 1929-a geodetic datum derived from a general adjustment of the first-order level nets of both the United States and Canada, formerly called Sea Level Datum of 1929. 


\title{
Geologic Ages and Accumulation Rates of Basalt-Flow Groups and Sedimentary Interbeds in Selected Wells at the Idaho National Engineering Laboratory, Idaho
}

\author{
by S.R. Anderson, Michael J. Liszewski, and L. DeWayne Cecil
}

\begin{abstract}
Geologic ages and accumulation rates, estimated from regressions, were used to evaluate measured ages and interpreted stratigraphic and structural relations of basalt and sediment in the unsaturated zone and the Snake River Plain aquifer at the Idaho National Engineering Laboratory (INEL) in eastern Idaho. Geologic ages and accumulation rates were estimated from standard linear regressions of 21 mean potassium-argon (K-Ar) ages, selected mean paleomagnetic ages, and cumulative depths of a composite stratigraphic section composed of complete intervals of basalt and sediment that were deposited in areas of past maximum subsidence. Accumulation rates also were estimated from regressions of stratigraphic intervals in three wells in and adjacent to an area of interpreted uplift at and near the Idaho Chemical Processing Plant (ICPP) and the Test Reactor Area (TRA) to allow a comparison of rates in areas of past uplift and subsidence.
\end{abstract}

Estimated geologic ages range from about 200 thousand to 1.8 million years before present and are reasonable approximations for the interval of basalt and sediment above the effective base of the aquifer, based on reported uncertainties of corresponding measured ages. Estimated ages between 200 and 800 thousand years are within the range of reported uncertainties for all $15 \mathrm{~K}-\mathrm{Ar}$ ages used in regressions and two out of three argon-argon $\left({ }^{40} \mathrm{Ar}{ }^{39} \mathrm{Ar}\right)$ ages of duplicate samples. Two sets of estimated ages between 800 thousand and 1.8 million years are within the range of reported uncertainties for all seven $\mathrm{K}-\mathrm{Ar}$ ages used in regressions, which include one shared age of about 800 thousand years. Two sets of ages were estimated for this interval because
$\mathrm{K}$-Ar ages make up two populations that agree with previous (1979) and revised (1995) ages of three paleomagnetic subchrons. The youngest set of ages is consistent with a $\mathrm{K}-\mathrm{Ar}$ age from the effective base of the aquifer that agrees with previous (1979) ages of the Olduvai Normal-Polarity Subchron. The oldest set of ages is consistent with an ${ }^{40} \mathrm{Ar} /{ }^{39} \mathrm{Ar}$ age of the same basalt flow that agrees with revised (1995) ages of the Olduvai Subchron. Regressions indicate that measured ages and stratigraphic interpretations are reasonable for basalt and sediment between the ages of 200 and 800 thousand years, the youngest deposits that could be evaluated using regressions. Regressions indicate potential errors in measured ages or stratigraphic interpretations for basalt and sediment between the ages of 800 thousand to 1.8 million years, the oldest deposits in the aquifer. Ages of older basalt flows in the aquifer are difficult to measure because many flows are altered. Stratigraphic relations of older basalt and sediment in the aquifer are difficult to determine because there are few cored intervals of this age.

Accumulation rates, estimated from regressions of stratigraphic intervals younger than 640 thousand years in three wells in and adjacent to an area of interpreted uplift at and near the ICPP and TRA, range from 59 to 282 feet/100,000 years and average $163 \mathrm{feet} / 100,000$ years, a rate that is nearly identical to a previous (1994) estimate of the subsidence rate between the INEL and the Yellowstone Plateau during the past 4 million years, about 164 feet $/ 100,000$ years. Accumulation rates estimated from regressions of the composite stratigraphic section, which is made up of stratigraphic intervals deposited in many areas of past subsidence for periods ranging from 200 to 700 thousand years during the past 1.8 million 
years, range from 171 to 270 feet/100,000 years and average 218 feet $/ 100,000$ years, a rate that is 33 percent greater than the previous (1994) estimated subsidence rate. Although average accumulation rates in wells at and near the ICPP and TRA agree with the previous (1994) estimated subsidence rate, these rates include two apparent rates that are a relative measure of the difference between past rates of contemporaneous subsidence and uplift, based on deep drill-hole data. The best estimates of past subsidence rates range from about 160 to 280 feet/100,000 years and average about 220 feet $/ 100,000$ years, based on the previous (1994) estimated subsidence rate and accumulation rates unaffected by differential subsidence or uplift. Estimated subsidence rates averaged about 192 feet $/ 100,000$ years and were much greater than accumulation rates during the past 200 thousand years, a period of greatly reduced volcanism. This interruption in basalt accumulation, which is unlike that of earlier periods and continues to the present day, includes most areas of the INEL.

\section{INTRODUCTION}

The Idaho National Engineering Laboratory (INEL) is operated by the U.S. Department of Energy (DOE) and covers about $890 \mathrm{mi}^{2}$ of the eastern Snake River Plain in eastern Idaho (fig. 1). Facilities at the INEL are used in the development of peacetime atomic-energy applications, nuclear-safety research, defense programs, and advanced energy concepts. Liquid radionuclide and chemical wastes generated at these facilities have been discharged to onsite infiltration ponds and disposal wells since 1952. Liquid-waste disposal has resulted in detectable concentrations of several waste constituents in water from the Snake River Plain aquifer underlying the INEL (Bartholomay and others, 1995).

Concern about the potential for migration of radioactive and chemical wastes in the unsaturated zone and aquifer has resulted in numerous studies of the subsurface at the INEL. In 1988, the U.S. Geological Survey (USGS) in cooperation with the DOE, began a site-wide study of the stratigraphy of basalt and sediment underlying the INEL to determine stratigraphic relations that might affect the movement of wastes. Three earlier reports, Anderson and Lewis (1989), Anderson (1991), and Anderson and Bowers (1995), describe stratigraphic relations and their implications regarding the movement of waste at the Radioactive Waste Management Complex (RWMC), the Idaho Chemical Processing Plant (ICPP), the Test Reactor Area (TRA), and Test Area North (TAN) (fig. 1). A fourth report, Anderson and others (1996a), describes stratigraphic relations in 333 wells at and near the INEL that include revised relations for the RWMC, ICPP, TRA, and TAN. Each of these reports describes measured and estimated ages of selected basaltflow groups and sedimentary interbeds in the unsaturated zone and aquifer. Estimated ages reported by Anderson and others (1996a) were determined from linear accumulation rates in selected wells, and were used to evaluate measured geologic ages with respect to their position in a composite stratigraphic section.

Measured ages must be evaluated with respect to estimated stratigraphic ages because ages have been measured for relatively few stratigraphic units, many of them have large associated uncertainties, and some do not agree with ages suggested or required by paleomagnetic, petrographic, chemical, or geophysical-log data. Comparisons of measured ages to ages estimated from accumulation rates are useful because they allow an integrated evaluation of ages and stratigraphy. These comparisons also allow an evaluation of structural interpretations, which at the INEL include subsidence (Anderson and Bowers, 1995; Smith and others, 1994) and uplift (Anderson and Bowers, 1995; Anderson, 1991).

\section{Purpose and Scope}

This report describes a range of estimated geologic ages and accumulation rates that are used to evaluate reported measured geologic ages and interpreted stratigraphic and structural relations of basalt and sediment in the unsaturated zone and the Snake River Plain aquifer at the INEL. Ages and maximum accumulation rates are estimated from standard linear regressions of selected mean potassium-argon (K-Ar) ages, selected mean paleomagnetic ages, and cumulative depths of a 


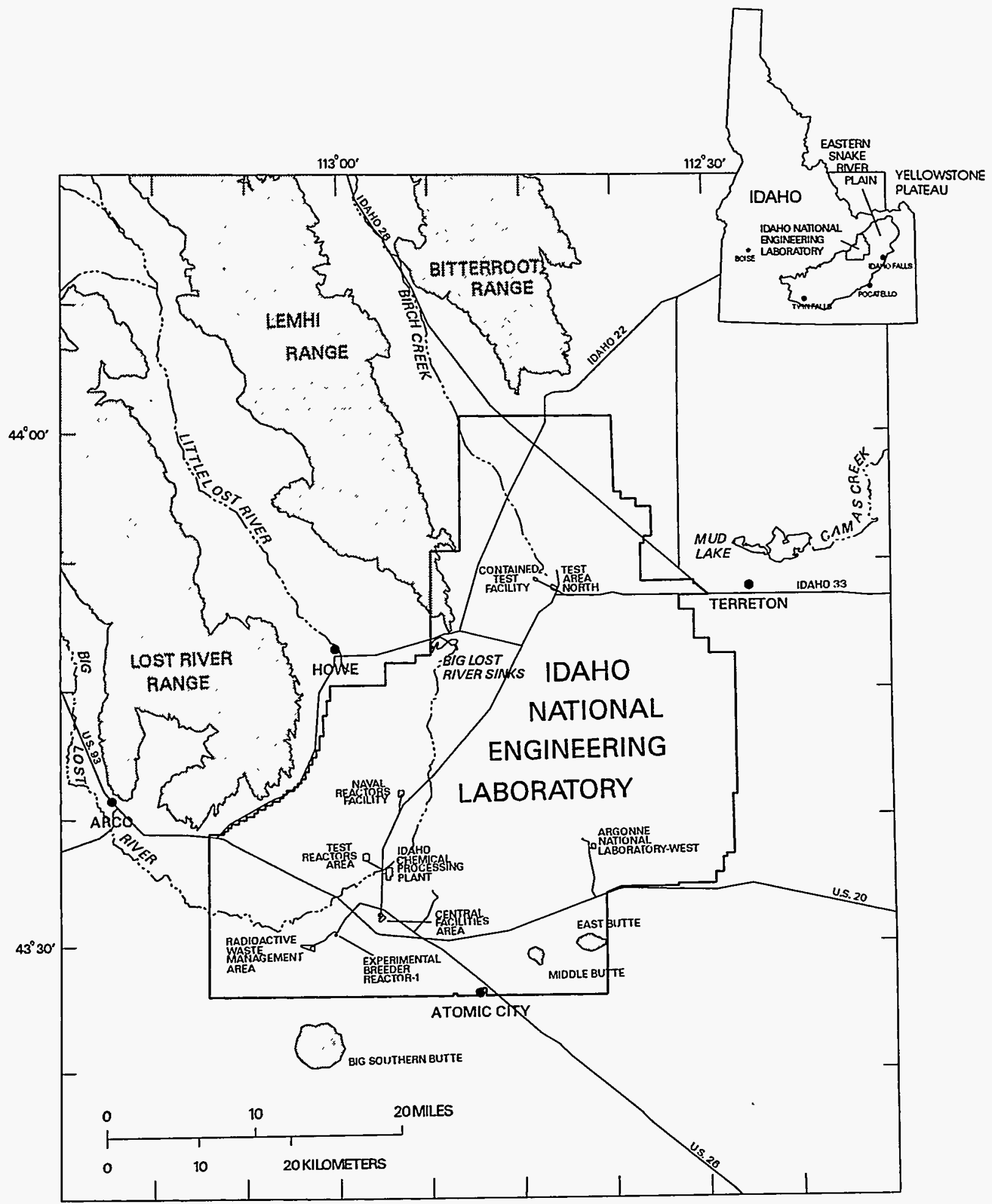

Figure 1. Location of the Idaho National Engineering Laboratory and selected facilities. 
composite stratigraphic section composed of complete intervals of basalt and sediment that were deposited in areas of past maximum subsidence. K-Ar ages and their associated uncertainties were obtained from the sources of data listed in table 1 (back of report) and from Kuntz and others (1994); ages generally range from about 200 thousand to 1.8 million years before present and include ages determined for basalt outcrops and cores. Paleomagnetic ages, which are referred to as previous (1979) and revised (1995), were obtained from Mankinen and Dalrymple (1979) and Berggren and others (1995); ages also include the age of an important paleomagnetic reversal identified only at the INEL (Champion and others, 1988). The composite stratigraphic section was constructed from the stratigraphic data presented by Anderson and others (1996a). Ages estimated from regressions of the composite stratigraphic section are compared to measured ages and stratigraphy to evaluate the agreement between $\mathrm{K}-\mathrm{Ar}$ ages and stratigraphic interpretations. Maximum accumulation rates estimated from regressions of the composite stratigraphic section are compared to accumulation rates estimated from regressions in three wells in and adjacent to an area of interpreted uplift at and near the ICPP and TRA and to the estimated rate of subsidence between the INEL and the Yellowstone Plateau (Smith and others, 1994), hereafter referred to as the previous (1994) estimated subsidence rate, to evaluate interpretations of past subsidence and uplift at the INEL.

Selected $\mathrm{K}$-Ar ages are used in regressions because reported ages for some stratigraphic units are from areas where stratigraphic relations are uncertain or disputed (Anderson and others, 1996a; Anderson and Bowers, 1995). Ages are estimated for 50 of the 230 stratigraphic units described by Anderson and others (1996a). Estimated ages are slightly to significantly different than and supersede those reported by Anderson and others (1996a) because revised (1995) paleomagnetic ages are considered. Estimated ages are provided to supplement measured ages until additional measured ages are obtained. Because the geologic setting of the INEL is complex, some interpretations of geologic ages, accumulation rates, stratigraphy, and structure in this report may change as additional data are obtained.

\section{Acknowledgments}

Technical assistance and data from numerous geologic investigations were obtained from Duane E. Champion, Marvin A. Lanphere, and Mel A. Kuntz, USGS, Geologic Division. Scott S. Hughes, Idaho State University, and Mary M. Donato, USGS, Water Resources Division, reviewed the report and provided many helpful suggestions concerning its content and organization.

\section{GEOLOGIC SETTING}

The INEL is located on the west-central part of the eastern Snake River Plain, a northeast-trending structural basin about $200 \mathrm{mi}$ long and 50 to $70 \mathrm{mi}$ wide (fig. 1). The INEL is underlain by a sequence of Tertiary and Quaternary volcanic rocks and sedimentary interbeds that is more than $10,000 \mathrm{ft}$ thick (Doherty and others, 1979; Whitehead, 1992; Smith and others, 1994; Hackett and others, 1994). The volcanic rocks consist mainly of basaltic lava flows, ash, and cinders in the upper part of the sequence and rhyolitic ash flows and tuffs of past caldera eruptions in the lower part. Basalt and sediment, which generally range in age from about 200 thousand to 4 million years before present, underlie the plain to depths ranging from about 2,200 to 3,800 ft below land surface in the southwestern part of the INEL. Ages of basalt and sediment in the unsaturated zone and the Snake River Plain aquifer generally range from about 200 thousand to 1.8 million years. Depth to the effective base of the aquifer ranges from about 800 to $1,700 \mathrm{ft}$ below land surface in the western half of the INEL (table 2, back of report).

Stratigraphic units identified in 333 wells completed in the unsaturated zone and aquifer include 121 basalt-flow groups and 102 sedimentary interbeds (Anderson and others, 1996a). Each basaltflow group consists of one or more distinct basalt flows deposited during a single, brief eruptive event (Kuntz and others, 1980); many older basalt 
flows in and below the aquifer are altered (Fromm and others, 1994). Sedimentary interbeds, which consist of well to poorly sorted deposits of clay, silt, sand, and gravel, accumulated on the ancestral land surface for hundreds to hundreds of thousands of years during periods of volcanic quiescence. Stratigraphic units are referred to as $\mathrm{Al}(1)$ through S5(1) (Anderson and others, 1996a). Basalt-flow groups and sedimentary interbeds $A B(1)$ through $L(2)$ range in age from about 200 to 800 thousand years, are widespread, and make up the unsaturated zone and uppermost part of the aquifer in most areas of the INEL. Basaltflow groups and sedimentary interbeds LM(1) through S5(1), which range in age from about 800 thousand to 1.8 million years, make up the unsaturated zone and aquifer at TAN (fig. 1) and the lowermost part of the aquifer elsewhere at the INEL (Anderson and Bowers, 1995).

Most wells in the southern and eastern parts of the INEL are completed in basalt and sediment that informally are referred to as basalt-flow groups $\mathrm{AB}$ through I and related sediment (Anderson, 1991). Flow groups $A B$ through I and related sediment range in age from about 200 to 640 thousand years and make up a stratigraphic section that is characterized by horizontal to inclined layers (fig. 2). Each basalt-flow group in the section was deposited during an eruption that lasted no longer than a few hundred years (Kuntz and others, 1980). The average length of time between these eruptions was about 10 to 20 thousand years, sufficiently long to accumulate thick layers of sediment in many areas. In places, such as the ICPP, TRA, and RWMC (fig. 2), the section is characterized by missing intervals of basalt and sediment. These interruptions in accumulation, which are referred to as hiatuses, generally lasted no more than a few tens of thousands of years at any one place. However, prolonged hiatuses, which are defined as missing intervals of basalt representing periods of at least 200 thousand years (table 3, back of report), cover the land surface in most areas of the INEL above basaltflow group $A B$ (fig. 2) and occur within the stratigraphic section at and near the ICPP, TRA, RWMC, and TAN (fig. 1).
The prolonged hiatus at the land surface resulted from significantly reduced volcanism during the past 200 thousand years; for millions of years until this time, the frequency and volume of eruptions were much greater (Kuntz and others, 1994; Anderson and Bowers, 1995). Prolonged hiatuses at and near the ICPP, TRA, RWMC, and TAN are attributed to differential subsidence and uplift during the past 1.8 million years (fig. 3 ). Volcanism, subsidence, and uplift resulted from the passage of the Yellowstone hot spot and subsequent intrusion of mafic material into the upper crustal layer of the eastern Snake River Plain about 4 to 6 million years ago (Pierce and Morgan, 1992; Sparlin and others, 1982). Subsidence began about 4 million years ago (Smith and others, 1994) and probably resulted from the cumulative effects of several mechanisms that may have included crustal extension, thermal contraction, withdrawal of basaltic magmas, isostatic adjustments, and compaction of sediment and caldera deposits. Uplift, which last occurred about 460 to 800 thousand years ago (fig. 3), probably resulted from the emplacement of laccoliths and domes within or beneath the subsiding stratigraphic section; alternatively, some areas of interpreted uplift may be the result of past differential subsidence or faulting. Regardless of how they formed, areas of interpreted uplift shown in figure 3 are now concealed by younger horizontal stratigraphic intervals and include only those areas that could be delineated using closely spaced wells and the stratigraphic relations of basalt-flow groups $\mathrm{AB}$ through I and related sediment (fig. 2); other similar areas probably occur elsewhere in the stratigraphic section underlying the INEL.

Accumulation rates estimated for intervals of basalt and sediment in selected wells provide a method to evaluate areas of past subsidence and uplift at the INEL (figs: 2-6). These rates, which are estimated using the geologic age and depth to the top of each basalt-flow group in areas of representative stratigraphy, must be averaged over hundreds of thousands of years to account for the long average time between basalt eruptions. Accumulation rates also must account for hiatuses related to vent constructs, periods of decreased volcanism, differential subsidence, and uplift; rates affected by hiatuses of more than a few tens 


\section{EXPLANATION}

B BASALT - Basalt-flow group composed of one or more related flows. Letter, $\mathrm{B}$, indicates sequence of group from top to bottom of section. Locally includes cinders and thin layers of sediment $\square$ CLAY, SILT, SAND, AND GRAVEL - Major groups. Locally includes cinders and basalt rubble

a

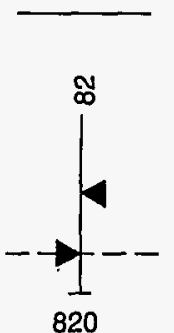

GEOLOGIC CONTACT - Queried where uncertain

WELL - Entry, 82, is local well identifier. Dashed line indicates measured or estimated water level in aquifer in 1990. Lower arrow indicates measured water level in aquifer in 1989 or 1990

Upper arrow indicates measured water level of perched ground water in 1989 or 1990 . Number 820 , at bottom of well is total depth of well in feet below land surface.

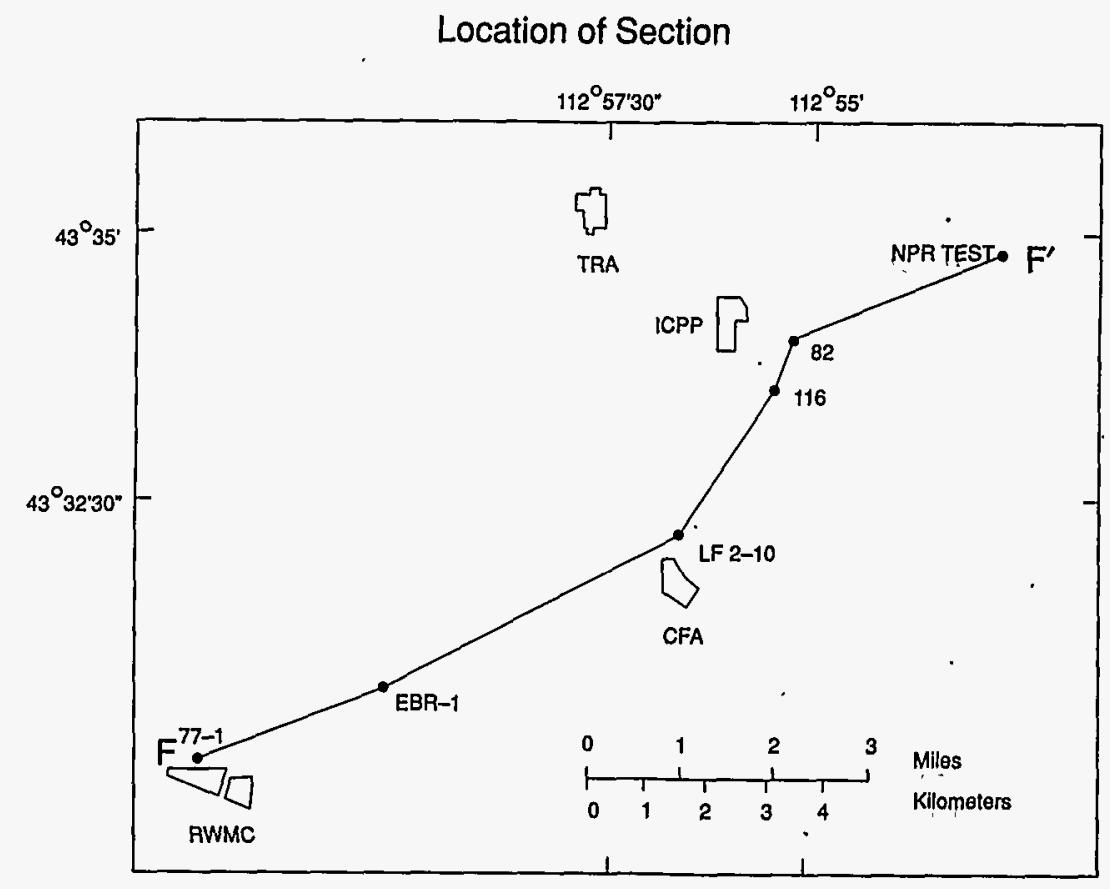

Figure 2. Geologic section F-F' through the Radioactive Waste Management Complex, the Idaho Chemical Processing Plant, and Well NPR TEST (from Anderson, 1991). 


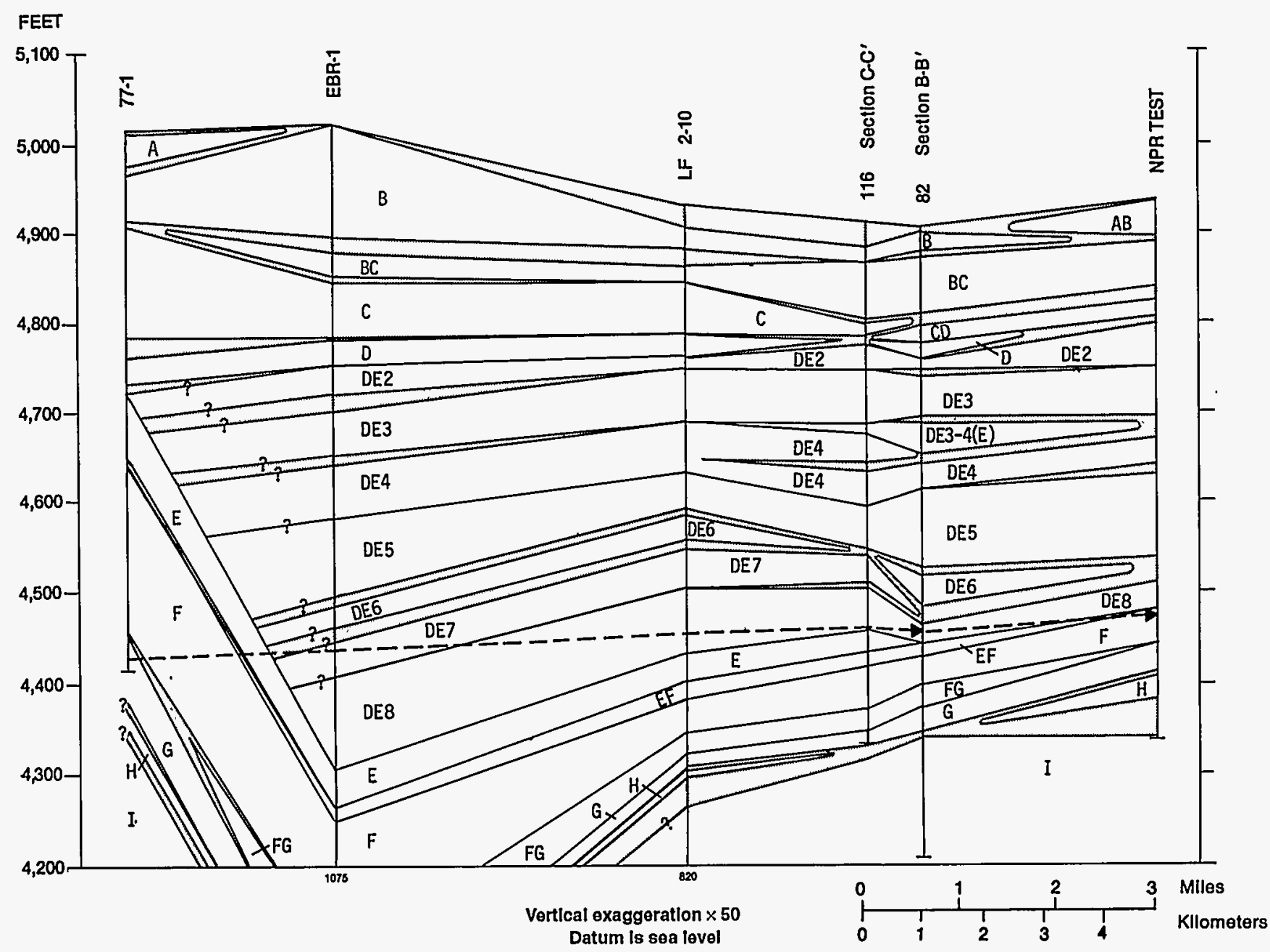

Figure 2. Geologic section F-F' through the Radioactive Waste Management Complex, the Idaho Chemical Processing Plant, and Well NPR TEST (from Anderson, 1991)—continued 


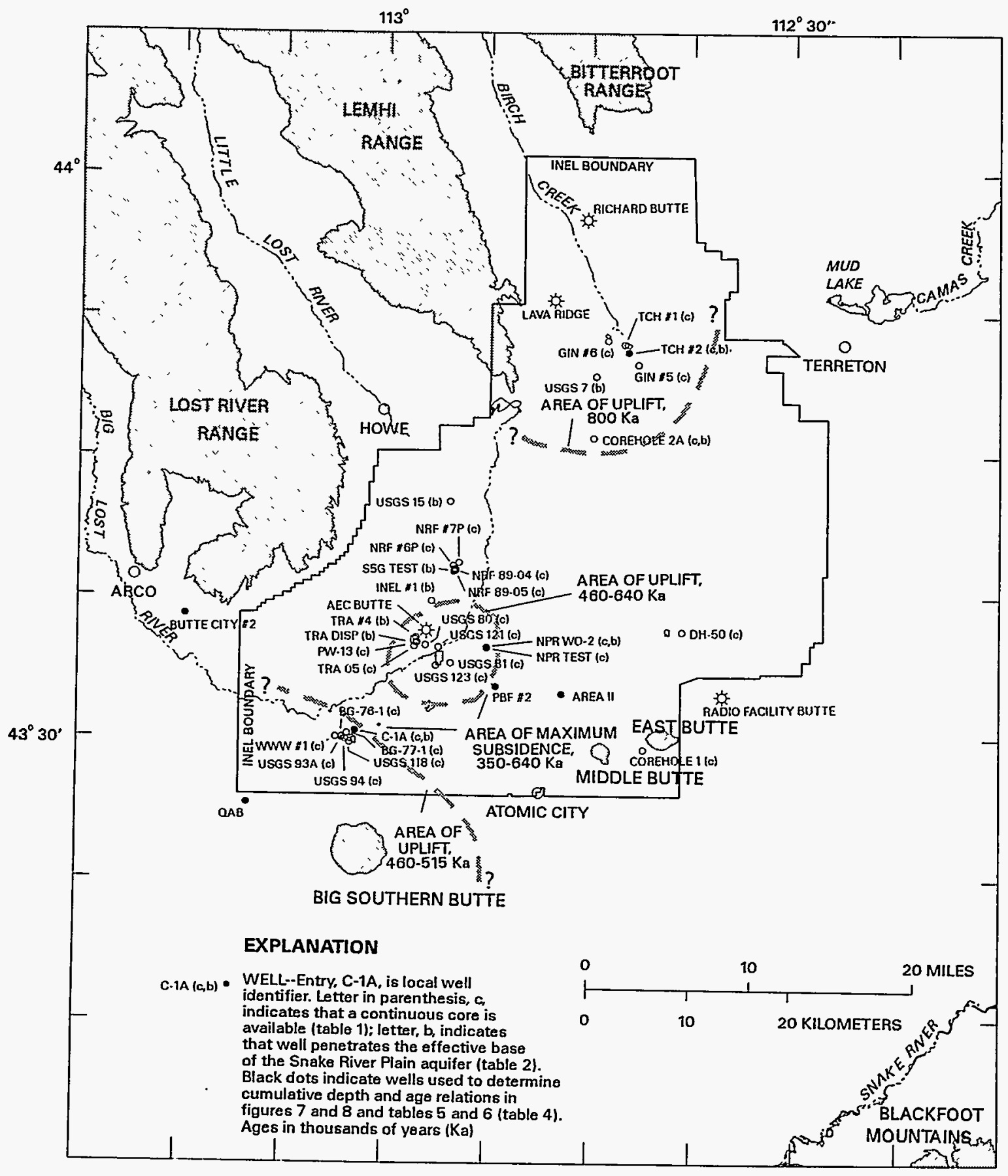

Figure 3. Locations of selected wells-and cores used to evaluate geologic ages, accumulation rates, stratigraphy, and structure of basalt-flow groups and sedimentary interbeds in the unsaturated zone and the Snake. River Plain aquifer at the Idaho National Engineering Laboratory. 
of thousands of years are referred to as apparent rales. Accumulation rates in wells USGS 80 and NPR TEST (figs. 4 and 5), which are apparent rates affected only by hiatuses and prolonged hiatuses attributed to past uplift at and near the ICPP and TRA (figs. 2 and 3), range from 59 to $149 \mathrm{ft} / 100,000$ years for stratigraphic intervals younger than 640 thousand years. By contrast, accumulation rates in well PBF \#2 (fig. 6), which is in an area of past maximum subsidence adjacent to uplift where stratigraphic intervals of this age generally are thicker and free of hiatuses (figs. 2 and 3), are as great as $282 \mathrm{ft} / 100,000$ years. The average of these rates, $163 \mathrm{ft} / 100,000$ years, is nearly identical to the previous (1994) estimated rate of subsidence between the INEL and the Yellowstone Plateau during the past 4 million years, about $164 \mathrm{ft} / 100,000$ years. The similarity of these rates suggest, as do interpreted stratigraphic relations (fig. 2), that accumulation rates are reasonable approximations of past subsidence rates and apparent subsidence rates for a given location and time at the INEL. However, without deep drill-hole data, apparent subsidence rates can be misleading. Apparent rates are a reasonable approximation of past subsidence rates if they represent motion with respect to a stable datum; however, some rates may violate this condition and, thus, may be a relative measure of the difference between two higher rates of subsidence or a rate of uplift superimposed on a rate of subsidence higher than that indicated by the apparent rate. All accumulation rates, if averaged over long enough periods of time, are apparent rates because all areas of the INEL, based on data from deep wells and cores (tables 1 and 2), are underlain by one or more prolonged hiatuses (table 3) caused by past differential subsidence or uplift. The youngest known hiatuses in the subsurface are attributed to uplift during the past 460 to 800 thousand years and underlie the areas at and near the ICPP, TRA, RWMC, and TAN (figs. 2 and 3). The best estimates of past subsidence rates at the INEL are obtained from linear accumulation rates that account for these hiatuses.

\section{COMPOSITE STRATIGRAPHIC SECTION}

A composite stratigraphic section was constructed to estimate ages and maximum accumulation rates of basalt and sediment in the unsaturated zone and the Snake River Plain aquifer at the INEL. The section, except for the uppermost part, was constructed using stratigraphic intervals in selected wells, such as the interval from 323 to $800 \mathrm{ft}$ in well PBF \#2 (fig. 3; table 4, back of report), that are in areas of past maximum subsidence and do not contain prolonged hiatuses, based on the stratigraphic data reported by Anderson and others (1996a). Sites D through I, which include wells AREA II, PBF \#2, QAB, NPR WO-2, C-1A, and TCH \#2 (fig. 3; table 4), were selected because each well contains a representative interval of basalt and sediment of a given age that meet these criteria. Site J, well NPR WO-2, was selected to evaluate the youngest known interval of basalt and sediment below the effective base of the aquifer. Sites A, B, and C were selected to evaluate a period of subsidence and greatly reduced basalt accumulation throughout most areas of the INEL during the past 200 thousand years. Sites A and C, wells Butte City \#2 and NPR TEST (fig. 3), are referred to as the subsidence and accumulation datums, respectively (table 4). Site $\mathrm{C}$ subsided $380 \mathrm{ft}$ with respect to site A during the past 200 thousand years (Anderson and Bowers, 1995). This difference, which for illustrative purposes is referred to as site B (table 4), represents the hypothetical approximate thickness of basalt that might have accumulated, given past accumulation/subsidence relations, were it not for a significant reduction in volcanism during the past 200 thousand years.

The composite stratigraphic section was constructed using depth and cumulative depth intervals from sites A through J (table 4). Geologic ages of deposits younger than about 800 thousand years generally agree with reported ages of paleomagnetic chrons and subchrons interpreted in this interval (Mankinen and Dalrymple, 1979; Champion and others, 1988; Berggren and others, 1995). Geologic ages of deposits older than about 800 thousand years generally range between previous (1979) and revised (1995) ages of three 


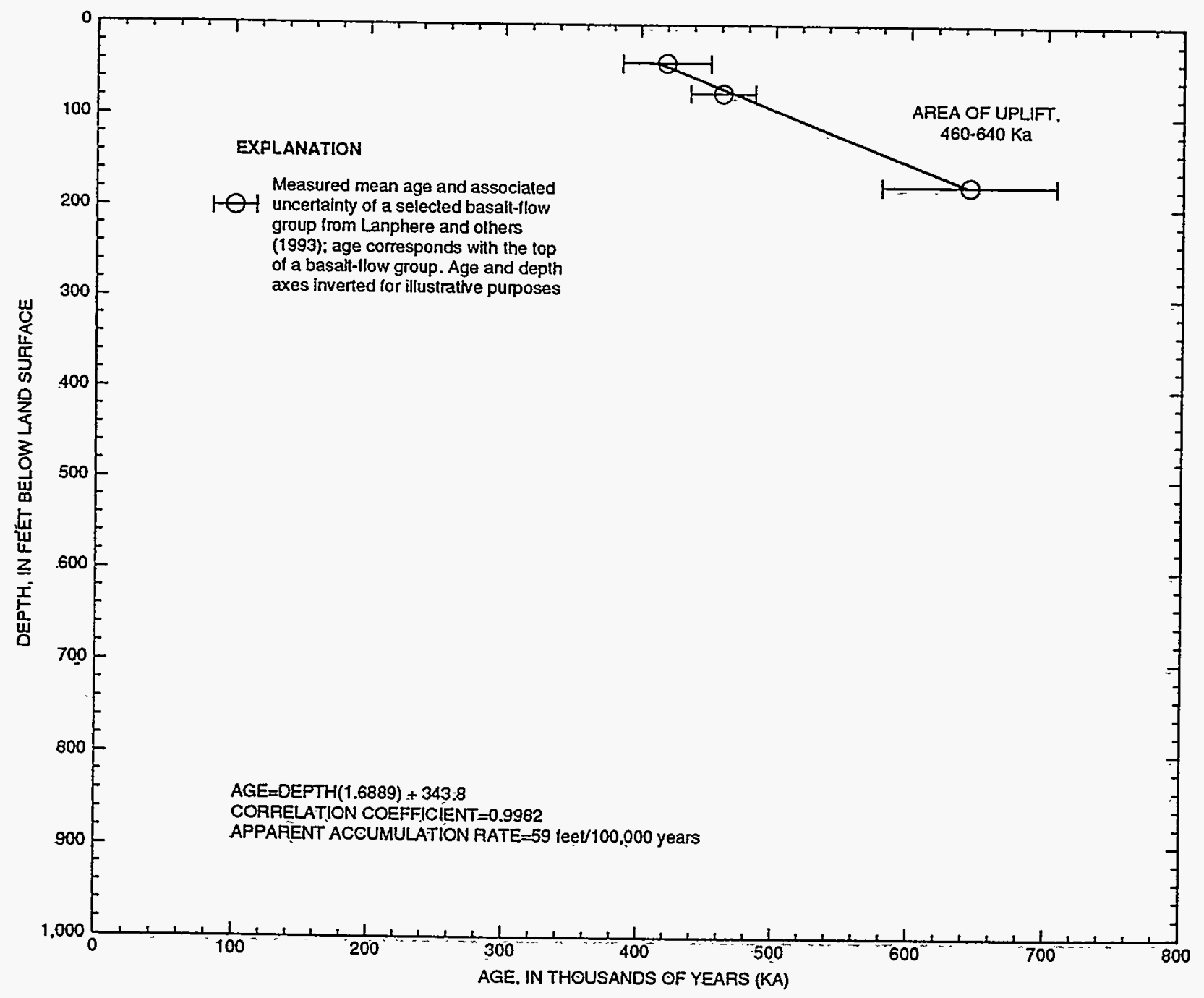

Figure 4. Relation between depths and measurcd geologic ages of basalt-flow groups DE4-5 through $I$ in well USGS 80 (fig. 3) at the Idaho National Engineering Laboratory. 


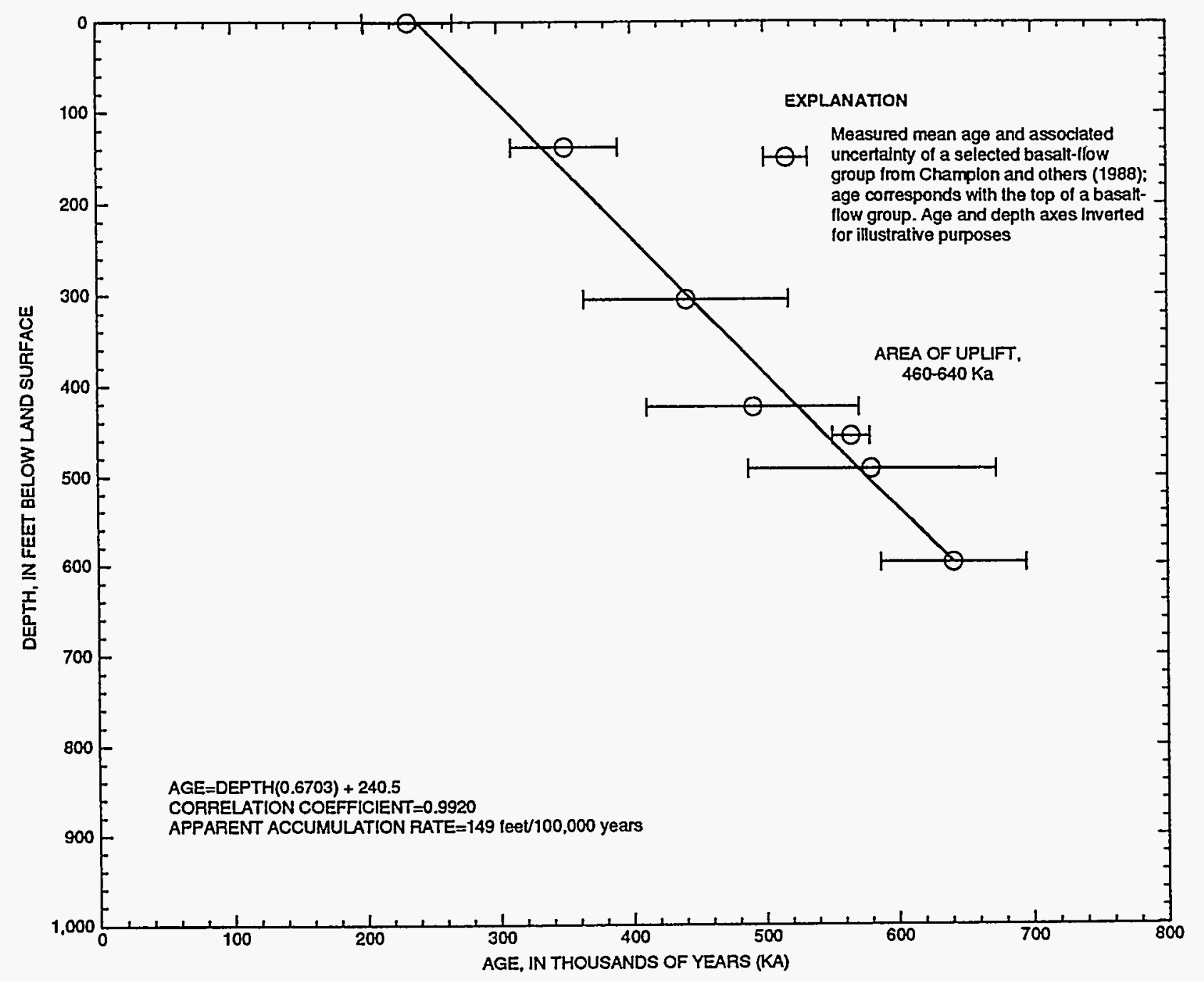

Figure 5. Relation between depths and measured geologic ages of basalt-flow groups AB through I in well NPR TEST (fig. 3) at the Idaho National Engineering Laboratory. 


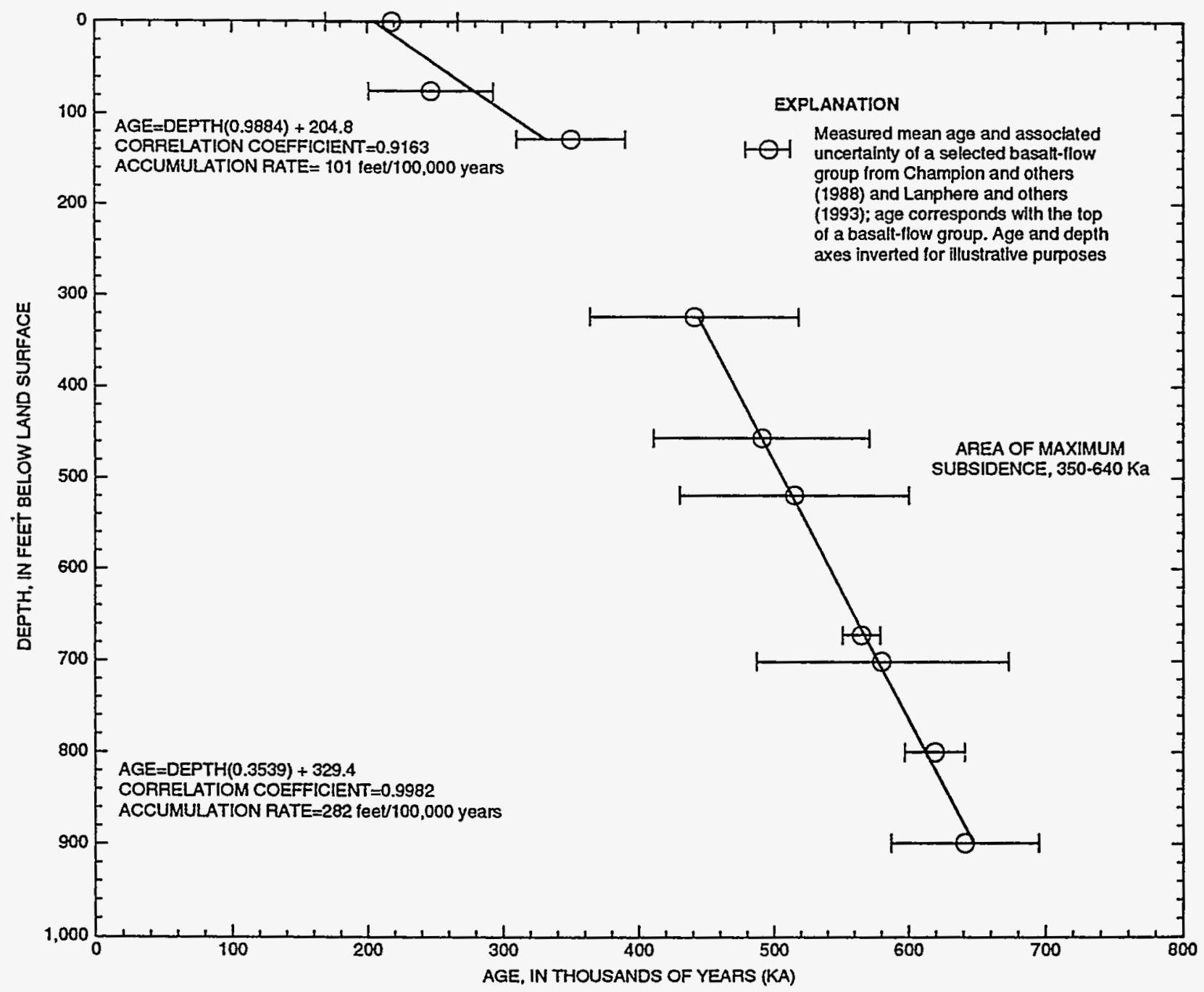

Figure 6. Relation between depths and measured geologic ages of basalt-flow groups AB through I in well PBF \#2 (fig. 3) at the Idaho National Engineering Laboratory. 
paleomagnetic subchrons interpreted in this interval. The composite stratigraphic section includes 50 of the 230 stratigraphic units identified by Anderson and others (1996a) and does not contain prolonged hiatuses in deposits older than about 200 thousand years. The remaining 180 units excluded from the section were deposited at other sites at and near the INEL and have ages similar to those of units included in the section. Thickness of the composite stratigraphic section is about twice that of measured sections of a similar age in wells C-1A and NPR WO-2 (fig. 3; table 2). Reduced thicknesses in these and other wells are attributed, in part, to structural movements and their related hiatuses (table 3 ).

\section{REGRESSION ANALYSIS}

Measured geologic ages and interpreted stratigraphic and structural relations of basalt-flow groups and sedimentary interbeds underlying the INEL were evaluated using ages and maximum accumulation rates estimated from standard linear regressions (Iman and Conover, 1983) of 21 mean $\mathrm{K}$-Ar ages, selected mean paleomagnetic ages, and cumulative depths of units in the composite stratigraphic section (figs. 7 and 8; tables 5 and 6, back of report). Each $\mathrm{K}$-Ar age is identified as a primary or a secondary age (figs. 7 and 8) depending on whether it was determined for a basaltflow group in the composite stratigraphic section or for a group of similar stratigraphic position not in the composite section. Paleomagnetic ages (figs. 7 and 8; table 6) include previous (1979) and revised (1995) ages of the boundary between the Brunhes Normal-Polarity Chron and the Matuyama Reversed-Polarity Chron and the interpreted boundaries of the Jaramillo, Cobb Mountain, and Olduvai Normal-Polarity Subchrons (Mankinen and Dalrymple, 1979; Berggren and others, 1995); ages also include the top of the Big Lost Reversed-Polarity Subchron (Champion and others, 1988). All ages were determined from basalt outcrops and cores distributed throughout the INEL and were correlated with the composite section using stratigraphic methods (Anderson and Bartholomay, 1995; Anderson and others, 1996a).
Primary and secondary K-Ar ages (figs. 7 and 8; table 6) are weighted mean ages reported by Champion and others (1988), Lanphere and others (1993), Lanphere and others (1994), and Kuntz and others (1994). Associated uncertainties of these ages are reported as one standard deviation; associated uncertainties of paleomagnetic ages were not reported. Additional published and unpublished $\mathrm{K}-\mathrm{Ar}$ and argon-argon $\left({ }^{40} \mathrm{Ar} /{ }^{39} \mathrm{Ar}\right)$ ages for units in the composite stratigraphic section, identified in tables 1 and 6, were used to evaluate regressions but were not included in regressions. Some K-Ar ages reported by Lanphere and others (1993), Lanphere and others (1994), and Kuntz and others (1994) were not included in regressions because they were determined for units of uncertain or disputed stratigraphic position (Anderson and others, 1996a; Anderson and Bowers, 1995). Primary, secondary, and paleomagnetic ages were given equal weight in regressions; however, ages and accumulation rates estimated from regressions are greatly influenced by the large number and range of reported ages of basalt cores from well NPR TEST for units younger than about 800 thousand years and by ages of paleomagnetic subchrons interpreted in basalt and sediment cores from wells C-1A, Corehole 2A, and NPR WO-2 (fig. 3) for units older than about 800 thousand years (figs. 7 and 8; tables 5 and 6). Linear rather than nonlinear regressions of mean ages and cumulative depths were used to estimate ages and accumulation rates of stratigraphic units because measured ages and stratigraphic relations are not yet known with sufficient precision to justify more rigorous methods. Although other regressions are possible (table 5), those used to construct accumulation graphs of the composite stratigraphic section (figs. 7 and 8 ) provide the most reasonable estimates of ages and accumulation rates based on available age and stratigraphic control and geologic reasoning.

Accumulation graphs showing the relations between geologic ages and depths of units in the composite stratigraphic section (figs. 7 and 8) were constructed using seven principal line segments, 1a, 1b, 1c, 2a, 2b, 3a, and 3b, that were determined from regressions ( $1 \mathrm{a}),\left(1 \mathrm{~b}_{2}\right),(1 \mathrm{c})$, (2a), (2b), (3a), and (3b) on table 5. Because the 


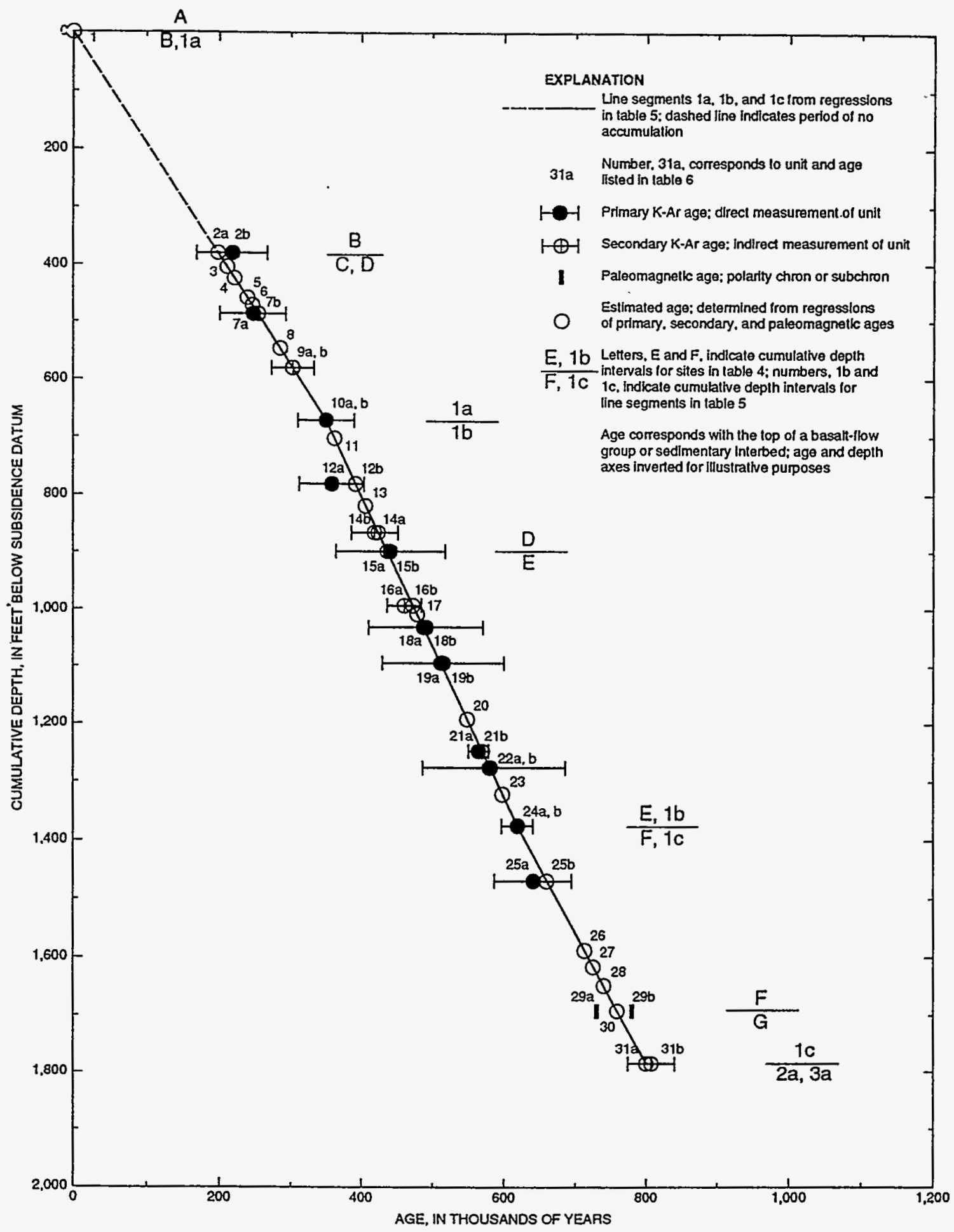

Figure 7. Relation between cumulative depths and geologic ages of selected basalt-flow groups and sedimentary interbeds in a composite stratigraphic section of the unsaturated zone and the Snake River Plain ayuifer at the Idaho National Engineering Laboratory-present to about 800 thousand years before present. [Subsidence datum is the land surface at well Butte City \#2 (table 4)] 


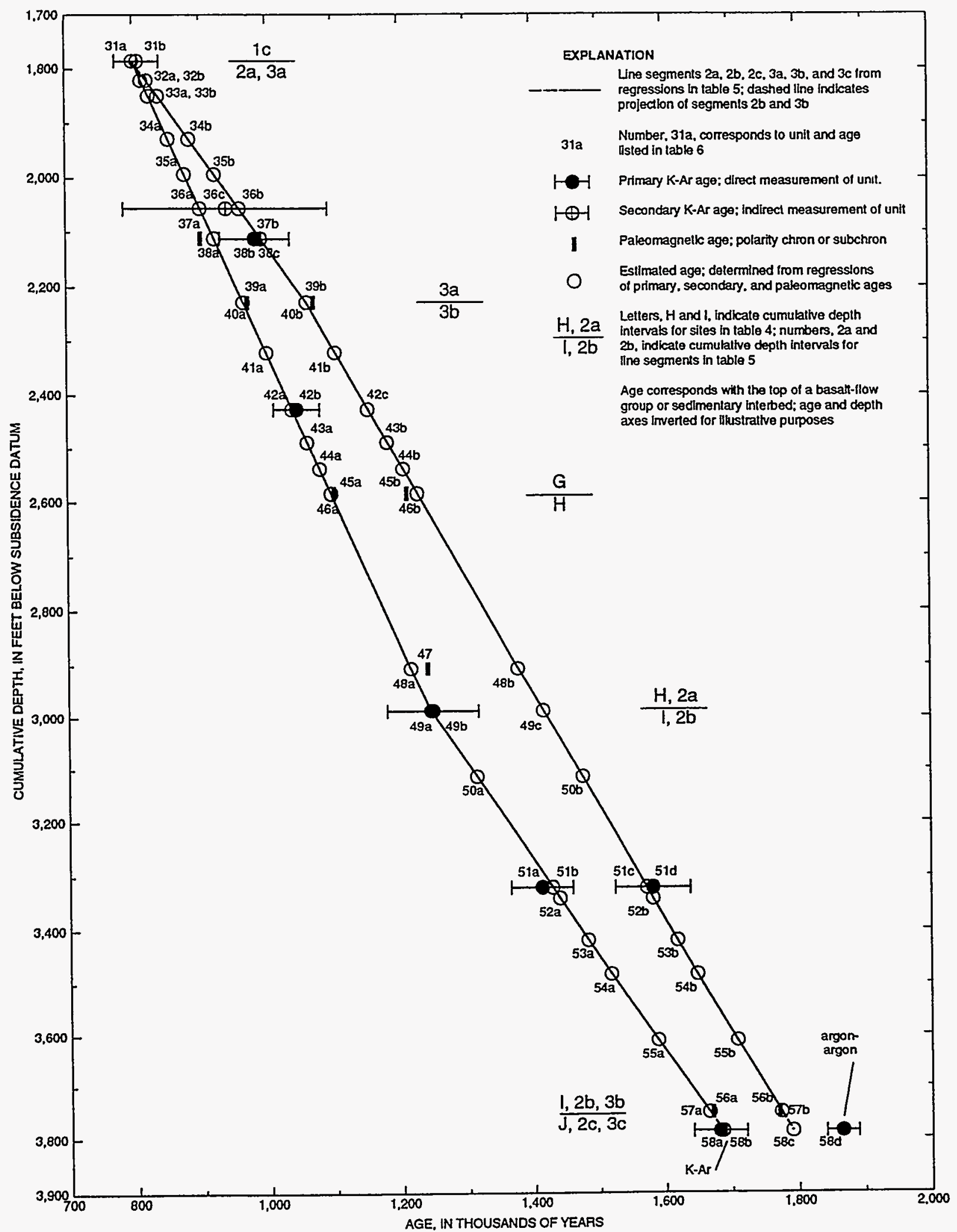

Figure 8. Relation between cumulative depths and geologic ages of selected basalt-flow groups and sedimentary interbeds in a composite stratigraphic section of the unsaturated zone and the Snake River Plain aquifer at the Idaho National Engineering Laboratory-about 800 to 1,800 thousand years before present. [Subsidence datum is the land surface at well Butte City \#2 (table 4)] 
end points of adjacent regressions differ by 3 to 12 thousand years (table 5), each line segment, except the top of $1 \mathrm{a}$ and the bottoms of $2 \mathrm{~b}$ and $3 \mathrm{~b}$, was determined using average or selected end points from two or more regressions. The top of line segment 1a was forced through zero age and depth without significantly changing regression (1a); the bottom ages and depths of line segments $2 \mathrm{~b}$ and $3 \mathrm{~b}$ are the same as those of regressions (2b) and (3b). Line segment $1 \mathrm{~b}$ was determined using regression $\left(1 b_{2}\right)$, which excluded one control point, number 12a in figure 7 and on table 5; regression $\left(1 b_{1}\right)$ includes this control point (table 5). Paleomagnetic ages, control points $29 \mathrm{a}$ and $29 \mathrm{~b}$ (fig. 7), which are previous (1979) and revised (1995) ages for the beginning of the Brunhes Normal-Polarity Chron, were not used for determining line segment $1 \mathrm{c}$ because they would have biased results. Previous (1979) paleomagnetic ages were used to supplement a small number of measured ages for determining line segments $2 \mathrm{a}$ and $2 \mathrm{~b}$. Revised (1995) paleomagnetic ages were used to supplement a small number of measured ages for determining line segments $3 a$ and $3 \mathrm{~b}$. Although they biased results, previous (1979) and revised (1995) paleomagnetic ages were used to provide sufficient age control for regressions and to bracket the range of measured ages of basalt and sediment older than about 800 thousand years above the effective base of the aquifer. Line segments $2 \mathrm{c}$ and $3 \mathrm{c}$ below the effective base of the aquifer were not determined using regressions because age and stratigraphic data for this interval are insufficient; segments $2 \mathrm{c}$ and $3 \mathrm{c}$ are projections of segments $2 b$ and $3 b$ and are shown by dashed lines in figure 8 . Additional regressions, (1a, 1b, 1c), (2a, 2b), (3a, 3b), and $(1 \mathrm{a}, 1 \mathrm{~b}, 1 \mathrm{c}, 2 \mathrm{a}, 2 \mathrm{~b}, 3 \mathrm{a}, 3 \mathrm{~b})$ (table 5) represent averaged data used to estimate average rates of accumulation in the composite stratigraphic section for the age interval shown. These regressions, which represent long intervals of time and disregard most age control, are not shown in figures 7 and 8 .

\section{GEOLOGIC AGES AND ACCUMULATION RATES}

Geologic ages estimated from regressions (table 6) agree with measured ages and interpreted stratigraphic relations, within the range of reported uncertainties of $\mathrm{K}$-Ar ages, for basaltflow groups and sedimentary interbeds younger than about 800 thousand years (fig. 7). The range of ages estimated for flow groups and interbeds older than about 800 thousand years (fig. 8) indicate potential errors in measured ages or stratigraphic interpretations for this interval. Estimated ages for all intervals are constrained by previous (1979) and revised (1995) paleomagnetic ages, but do not agree precisely with either interpretation. Estimated geologic ages are reasonable approximations of ages for basalt and sediment younger than about 800 thousand years, based on the regression analysis; geologic ages of deposits older than about 800 thousand years probably range between the ages estimated from duplicate regressions (table 6). Accumulation rates estimated from regressions (table 5) are reasonable approximations of maximum accumulation and subsidence rates during the past 1.8 million years for a given site and time, based on the stratigraphic data reported by Anderson and others (1996a).

\section{Geologic Ages}

Geologic ages were estimated for 50 stratigraphic units that include 47 basalt-flow groups and 3 sedimentary interbeds. Mean estimated ages range from 198 thousand to 1.790 million years before present and are reasonable approximations of the geologic ages of selected basalt-flow groups and sedimentary interbeds in the unsaturated zone and the Snake River Plain aquifer at the INEL. Agreement between measured and estimated ages is greatest for ages ranging from about 200 to 800 thousand years, line segments $1 \mathrm{a}, 1 \mathrm{~b}$, and $1 \mathrm{c}$ (fig. 7; table 6), and is least for ages ranging from about 800 thousand to 1.8 million years, line segments $2 a, 2 b, 2 c, 3 a, 3 b$, and $3 c$ (fig. 8; table 6). Ages of basalt and sediment younger than about 200 thousand years could not be evaluated using this method and are described by Forman and others (1993), Forman and others (1994), and Kuntz and others (1994).

Ages estimated from line segments $1 \mathrm{a}, 1 \mathrm{~b}$, and 1c, about 200 to 800 thousand years, are based on $14 \mathrm{~K}$-Ar ages. Agreement between measured and estimated ages among line segments $1 \mathrm{a}, 1 \mathrm{~b}$, and 
$1 \mathrm{c}$ is greatest for ages ranging from about 350 to 620 thousand years, line segment $1 \mathrm{~b}$, and least for ages ranging from about 620 to 800 thousand years, line segment 1c. Agreement between K-Ar, ${ }^{40} \mathrm{Ar} /{ }^{39} \mathrm{Ar}$, and estimated ages for control points 21 and 24 and between $\mathrm{K}-\mathrm{Ar}$ and estimated ages for control points $2,7,9,10,12,14,15,16,18$, $19,22,25$, and 31 in line segments $1 \mathrm{a}$ and $1 \mathrm{~b}$ indicate that $\mathrm{K}$-Ar ages can reasonably measure geologic ages of young basalt flows at the INEL (fig. 7; table 6). However, estimated ages determined from line segment $1 \mathrm{c}$ do not agree with an ${ }^{40} \mathrm{Ar} /{ }^{39} \mathrm{Ar}$ age for control point 25 and the revised (1995) age for the beginning of the Brunhes Normal-Polarity Chron, control point $29 \mathrm{~b}$ (fig. 7; table 6). These discrepancies may be related to potential errors in the geochronology, stratigraphy, or regression analysis.

Ages estimated from line segments $2 \mathrm{a}, 2 \mathrm{~b}$, and $2 c$, about 800 thousand to 1.685 million years, are based on four $\mathrm{K}$-Ar ages, control points $31 \mathrm{~b}, 42 \mathrm{~b}$, $49 \mathrm{~b}$, and 51a (fig. 8; tables 5 and 6), that generally agree with previous (1979) paleomagnetic ages. A $\mathrm{K}$-Ar age, control point 58a in line segment 2c (fig. 8; table 6), determined from basalt that cooled during the Olduvai Normal-Polarity Subchron agrees with these ages but is considered unreliable by the laboratory (M.A. Lanphere, USGS, written commun., 1992). Ages estimated from line segments $3 a, 3 b$, and $3 c$, about 800 thousand to 1.790 million years, are based on four $\mathrm{K}$-Ar ages, control points $31 \mathrm{~b}, 36 \mathrm{c}, 38 \mathrm{~b}$, and 51d (fig. 8; tables 5 and 6), that generally agree with revised (1995) paleomagnetic ages. $\mathrm{An}^{40} \mathrm{Ar} /{ }^{39} \mathrm{Ar}$ age, control point 58d in line segment $3 \mathrm{c}$ (fig. 8; table 6), although older than the estimated age predicted from line segment $3 \mathrm{~b}$, agrees with revised ages for the Olduvai Normal-Polarity Subchron (M.A. Lanphere, USGS, written commun., 1995); because of this age, estimated ages determined from line segments $3 a, 3 b$, and $3 c$ are more likely than those of segments $2 \mathrm{a}, 2 \mathrm{~b}$, and $2 \mathrm{c}$ to approximate geologic ages of older stratigraphic units. Neither set of estimated ages agrees with K-Ar ages corresponding to points $52,53,54$, and 55 in table 6, ages that were considered too old by Anderson and Bowers (1995) based on stratigraphic arguments. Each set of estimated ages is based, in part, on different $\mathrm{K}$-Ar ages, control points 51a and 51d in line segments $2 \mathrm{~b}$ and $3 \mathrm{~b}$ (fig. 8), determined from the same interval of basalt in adjacent cores at TAN (fig. 1) that may (Anderson and Bowers, 1995) or may not (Lanphere and others, 1994) be the same stratigraphic unit. These discrepancies may be related to potential errors in the geochronology, stratigraphy, or regression analysis. Ages of older basalt flows in the aquifer are difficult to measure because many flows are altered. Stratigraphic relations of older basalt and sediment in the aquifer are difficult to determine because there are few cored intervals of this age (table 2).

The associated uncertainties for the estimated ages in table 6 are calculated standard errors and are a measure of the scatter about a given regression line. These errors were calculated using a modification of the following equation from Spiegel (1975) and Davis (1986):

$$
S \sqrt{\frac{\sum\left(y-y_{\text {est }}\right)^{2}}{n}}
$$

where,

$S$ is the standard error of the estimated geologic age,

$\Sigma$ is the summation,

$y$ is a measured geologic age used in the linear regression,

$y_{\text {est }}$ is the estimated geologic age for a given depth, and

$n$ is the number of observations; $n$ equals 2 for these calculations.

For this analysis, one measured geologic age was used with one corresponding estimated geologic age for the error calculations. Therefore, the sum symbol, $\Sigma$, was dropped from equation 1 and $n$ was set equal to 2 . Because there are more estimated ages than corresponding measured ages in table 6, two successive measured ages were averaged and the resultant age was used as a guide for selecting the corresponding estimated ages to be used in equation 1 . For example, for regression line segment 1a in table 6 , the first two measured ages, 218,000 and 247,000 years, have an average of 232,500 years. All estimated ages for line seg- 
ment $1 \mathrm{a}$ less than 232,500 years were used with the measured age of 218,000 years in equation 1 to calculate an associated standard error. All estimated ages between 232,500 and 275,000 years, the average of the next two successive measured ages, 247,000 and 303,000 years, were used with the measured age of 247,000 years in equation 1 to calculate an associated standard error. This procedure was repeated for all estimated ages in table 6 .

These standard errors are an estimate of the precision of the estimated ages in relation to measured ages used for each linear regression (table 6). Therefore, as the cumulative depth for an estimated age approaches the corresponding cumulative depth for a measured age, a control point for a given regression line, the calculated uncertainty for the estimated age becomes smaller. Because the true uncertainties of estimated ages are probably larger than those of measured ages, the standard errors in table 6 should only be used as a guide to evaluate the precision of each estimated age with respect to its associated measured age.

\section{Accumulation Rates}

Accumulation rates estimated from regressions of selected stratigraphic intervals in wells AREA II, PBF \#2, QAB, NPR WO-2, C-1A, and TCH \#2 (table 4) range from 171 to $270 \mathrm{ft} / 100,000$ years (table 5) and are representative of rates that occurred in areas of maximum subsidence for periods ranging from about 200 to 700 thousand years during the past 1.8 million years. Maximum accumulation rates for basalt and sediment younger than about 800 thousand years, line segments $1 \mathrm{a}, 1 \mathrm{~b}$, and $1 \mathrm{c}$ (fig. 7; table 5), range from 192 to $262 \mathrm{ft} /$ thousand years. Maximum rates for basalt and sediment older than about 800 thousand years range from 182 to $270 \mathrm{ft} / 100,000$ years using line segments $2 a$ and $2 b$ and from 171 to $213 \mathrm{ft} / 100,000$ years using line segments $3 \mathrm{a}$ and $3 b$ (fig. 8; table 5).

Maximum accumulation rates estimated from regressions of the composite stratigraphic section, 171 to $270 \mathrm{ft} / 100,000$ years (table 5), are about 15 to 358 percent greater than the apparent rates of 59 to $149 \mathrm{ft} / 100,000$ years in wells USGS 80 and
NPR TEST (figs. 4 and 5) attributed to uplift at and near the ICPP and TRA during the past 640 thousand years (figs. 2 and 3). Maximum rates for line segments $1 \mathrm{~b}$ and 2a, 262 and $270 \mathrm{ft} / 100,000$ years (table 5), are about 4 to 7 percent less than the maximum rate of $282 \mathrm{ft} / 100,000$ years in well PBF \#2 (fig. 6) in the area adjacent to uplift (figs. 2 and 3). If the apparent rates in wells USGS 80 and NPR TEST are an approximate measure of past subsidence rates, these rates ranged from 59 to $282 \mathrm{ft} / 100,000$ years and averaged $163 \mathrm{ft} /$ 100,000 years during the past 640 thousand years at and near the ICPP and TRA. However, if the apparent rates in wells USGS 80 and NPR TEST are, instead, a relative measure of the difference between past rates of contemporaneous subsidence and uplift, a relation that is suggested by stratigraphic data from the deepest continuouslycored well at the INEL, well NPR WO-2 (fig. 3; table 1), subsidence rates in this area ranged from more than 149 to $282 \mathrm{ft} / 100,000$ years. On the basis of the previous (1994) estimated subsidence rate between the INEL and the Yellowstone Plateau, $164 \mathrm{ft} / 100,000$ years, the maximum accumulation rate in well PBF \#2, $282 \mathrm{ft} / 100,000$ years (fig 6), and the maximum accumulation rates estimated for the composite stratigraphic section, 171 to $270 \mathrm{ft} / 100,000$ years (table 5), subsidence rates at and near the ICPP and TRA and elsewhere at the INEL probably ranged from about 160 to $280 \mathrm{ft} / 100,000$ years and averaged about $220 \mathrm{ft} / 100,000$ years during the past 1.8 million years. Although accumulation rates were similar to subsidence rates for periods ranging from about 200 to 700 thousand years (table 5), overall apparent accumulation rates must have been less than these rates to account for prolonged hiatuses in the stratigraphic section (table 3). Prolonged hiatuses, which are attributed to differential subsidence and uplift until the past 200 thousand years, averaged about 600 thousand years and 38 percent of the total possible accumulation time during the period from 200 thousand to 1.8 million years in seven representative wells at the INEL (table 3). On the basis of this relation, apparent accumulation rates probably ranged from about 99 to $174 \mathrm{ft} / 100,000$ years and averaged about $136 \mathrm{ft} / 100,000$ years, 38 percent less than the probable subsidence rates during the past 1.8 million years. These rates disregard the prolonged 
hiatus during the past 200 thousand years above basalt-flow group $A B(10)$ in well NPR TEST (table 3) because the hiatus is above the accumulation datum of the composite stratigraphic section (fig. 7, line segment 1a; table 4) and is not representative of other past accumulation rates and apparent accumulation rates at the INEL.

\section{STRATIGRAPHIC AND STRUCTURAL IMPLICATIONS}

The stratigraphic section underlying the INEL is made up of overlapping intervals of basalt and sediment that accumulated in areas of past volcanism and subsidence (Anderson and Bowers, 1995; Anderson, 1991). These areas covered hundreds of square miles, were active for periods ranging from 200 to 700 thousand years, shifted across a $1,000 \mathrm{mi}^{2}$ area during the past 1.8 million years, and were preceded and followed by periods of reduced accumulation. Periods of maximum accumulation in each area were accompanied by an approximate volumetric equilibrium between basaltic volcanism, accumulation, and subsidence. Periods of reduced accumulation in each area were accompanied by differential subsidence or uplift. As a result, the stratigraphic section is characterized by a succession of widespread stratigraphic intervals bounded by local offsets and hiatuses and differences in overall thickness as great as 100 percent. The section also is characterized by maximum long-term apparent accumulation rates that are about 38 percent less than past subsidence rates in areas of greatest thickness, a difference identical to that between the approximate average land-surface altitudes of the INEL and the Yellowstone Plateau, about 5,000 and $8,000 \mathrm{ft}$ above sea level, respectively. As used in this report, offsets refer to abrupt changes in dip of stratigraphic intervals that probably resulted from past differential subsidence or uplift. Although possible in some areas, past faulting is not required to explain these offsets.

The complexity of the stratigraphic section at any one place can be demonstrated by a 3,800-ft thick section of basalt and sediment that overlies rhyolite in nested cores obtained from wells NPR WO-2 and NPR TEST (table 1) in the area of interpreted uplift at and near the ICPP and TRA (fig. 3). Thickness of the section, which ranges in age from about 200 thousand to 4 million years (Smith and others, 1994), is only about 13 percent greater than the composite stratigraphic section below the accumulation datum (figs. 7 and 8; table 4), a representation of the composite thickness of all intervals deposited in areas of maximum subsidence during the past 1.8 million years. Thickness of the equivalent interval above the effective base of the aquifer in wells NPR WO-2 and NPR TEST, 1,660 ft (table 2), is about 51 percent less than the composite stratigraphic section below the accumulation datum, a difference that is attributed to hiatuses in the interval (table 3). Estimated accumulation/subsidence rates for this interval, which contains several short hiatuses near its top and a prolonged hiatus of about 600 thousand years near its base (table 3 ), range from 149 to $226 \mathrm{ft} / 100,000$ years disregarding the prolonged hiatus (fig. 5; table 5, line segments 1c, 3a, and 3b). The average accumulation/ subsidence rate for the interval, disregarding the prolonged hiatus and using top and bottom ages of about 200 thousand and 1.2 million years, respectively (table 3 ), is $166 \mathrm{ft} / 100,000$ years, a rate that is nearly identical to the previous (1994) estimated subsidence rate between the INEL and the Yellowstone Plateau during the past 4 million years. The average apparent accumulation rate for this interval using top and bottom ages that encompass the prolonged hiatus, about 200 thousand and 1.8 million years, respectively (table 3 ), is about $104 \mathrm{ft} / 100,000$ years, a rate that is 36 percent less than the previous (1994) estimated subsidence rate, 37 percent less than the rate above the hiatus, and nearly identical to an apparent rate estimated from the 38 percent difference between the average prolonged hiatus and total accumulation time during the past 1.8 million years at the INEL. These rates, which probably are similar to those of the interval below the effective base of the aquifer based on its thickness $(2,100 \mathrm{ft})$ and age difference ( 2.2 million years), suggest a mechanism of continuous long-term subsidence accompanied by periodic uplift at this location. Hiatuses attributed to uplift, which last occurred in this area 460 to 640 thousand years ago (fig. 3), make up about 38 percent of the total possible accumulation time for the period from 200 thousand to 1.8 million years. The average accumulation/ 
subsidence rate for the period from 200 thousand to 1.2 million years, $166 \mathrm{ft} / 100,000$ years, is about 24 percent less than the average estimated maximum rate at the INEL for the past 1.8 million years, $220 \mathrm{ft} / 100,000$ years. The average apparent accumulation rate for the period from 200 thousand to 1.8 million years, $104 \mathrm{ft} / 100,000$ years, is about 53 percent less than the average maximum accumulation rate. The interval above the effective base of the aquifer in well NPR WO-2 is about the same thickness as that in well $\mathrm{C}-1 \mathrm{~A}$ in the area of interpreted uplift at and near the RWMC (fig. 3; table 2). This relation suggests that areas at and near the ICPP, TRA, and RWMC shared a similar history of subsidence accompanied by periodic uplift during the past 1.8 million years.

Although the layering of the stratigraphic section is relatively horizontal beneath most areas of the INEL, the layers of some stratigraphic intervals older than about 500 thousand years are offset by hundreds of feet as a result of past differential subsidence and uplift. Past uplift near the ICPP, TRA, RWMC, and TAN (fig. 3) produced offsets ranging from about 300 to $800 \mathrm{ft}$ during the past 800 thousand years (Anderson and Bowers, 1995; Anderson, 1991). Past differential subsidence in the area beneath the present-day Big Lost River (fig. 3) produced offsets ranging from about 700 to $1,500 \mathrm{ft}$ in stratigraphic intervals older than about 800 thousand years. The greatest offset attributed to uplift is about $270 \mathrm{ft} /$ $\mathrm{mi}$ in intervals older than about 500 thousand years between wells C-1A and EBR- 1 just north of the RWMC (figs. 2 and 3). The greatest offset beneath the Big Lost River is about $330 \mathrm{ft} / \mathrm{mi}$ in rhyolite older than about 4 million years in wells NPR WO-2 and INEL \#1 that are east and west of the river, respectively (fig. 3 ). This offset is attributed to past differential subsidence because the thicknesses of basalt and sediment intervals above and below the effective base of the aquifer in well NPR WO-2 are each about 74 percent greater than those of respective intervals in well INEL \#1. Furthermore, the cumulative difference in thickness of these intervals, $1,600 \mathrm{ft}$, is about the same as the difference between the altitudes of the underlying rhyolite in each well, about 1,200 and $2,700 \mathrm{ft}$ above sea level, respectively. There- fore, the difference in altitudes of rhyolite in wells NPR WO-2 and INEL \#1 probably resulted from past differential subsidence beneath the Big Lost River (Anderson and Bowers, 1995) rather than from original topographic relief as suggested by Smith and others (1994). The river overlies an area of interpreted uplift (fig. 3), attributed to a concealed laccolith or dome (Anderson, 1991), that is younger than the offset attributed to differential subsidence in this area. Possible faulting related to past differential subsidence in this area might explain the position and origin of this uplift as well as the offset in older stratigraphic intervals between wells NPR WO-2 and INEL \#1.

The total thickness of the basalt and sediment section above the effective base of the aquifer is not known in many areas but can be evaluated using estimated accumulation and subsidence rates and the thickness of the composite stratigraphic section below the accumulation datum, 3,371 ft (figs. 7 and 8; tables 4 and 5). The thickness of the section in five wells mountainward of the Big Lost River, wells USGS 15, S5G TEST, INEL \#1, TRA \#4, and TRA DISP (fig. 3), averages about $900 \mathrm{ft}$ (table 2) and includes only basalt and sediment younger than about 800 thousand years (fig. 7). The thickness of the section in three wells in the area of interpreted uplift at and near TAN, wells TCH \#2, USGS \#7, and Corehole 2A (fig. 3), averages about $875 \mathrm{ft}$ (table 2) and includes only basalt and sediment older than about 800 thousand years (fig. 8). Thickness of the section in two wells in the areas of interpreted uplift at and near the ICPP, TRA, and RWMC, wells NPR WO-2 and C-1A (fig. 3), averages about $1,685 \mathrm{ft}$ (table 2 ) and includes basalt and sediment that are younger and older than 800 thousand years (figs. 7 and 8). The average thickness of the section mountainward of the Big Lost River and at and near TAN is about 73 percent less than that of the composite stratigraphic section below the accumulation datum. The average thickness of combined sections older and younger than 800 thousand years, in these areas, $1,775 \mathrm{ft}$, is about 47 percent less than that of the composite stratigraphic section below the accumulation datum and about 5 percent greater than that of the average section in wells NPR WO-2 and $\mathrm{C}-1 \mathrm{~A}$, the thickest known section above the 
effective base of the aquifer at the INEL. These relations suggest that differential subsidence and uplift reduced the apparent accumulation rates and thicknesses of the stratigraphic section, compared to those of the composite stratigraphic section, by about 50 to 75 percent in the western half of the INEL. The thickness of the stratigraphic section in some areas between and east of the ICPP, RWMC, and TAN may be greater than that of the section in wells NPR WO-2 and C-1A, based on interpreted stratigraphic relations and estimates of maximum accumulation/subsidence rates (figs. 2-6; table 5) However, the maximum thickness of the section must be less than that of the composite stratigraphic section below the accumulation datum because maximum rates occurred for relatively short periods of time, shifted across the INEL during the past 1.8 million years, and were preceded and followed by periods of reduced accumulation and hiatuses.

Given the range of estimated maximum accumulation/subsidence rates and the thickness of the composite stratigraphic section (figs. 7 and 8; table 5), hiatuses and apparent accumulation rates related to differential subsidence and uplift are required to explain the stratigraphic data reported by Anderson and others (1996a) and the known thicknesses of basalt and sediment younger than about 1.8 million years at the INEL. Hiatuses and apparent accumulation rates, such as those in well NPR WO-2, also are required to explain why, given that maximum accumulation and subsidence rates were similar during the past 1.8 million years, the altitude of the land surface at the INEL, about 5,000 ft, is about 3,000 ft below that of the Yellowstone Plateau. The difference in altitude between these areas, about 38 percent, is nearly identical to the difference between the apparent accumulation rate of $104 \mathrm{ft} / 100,000$ years and the average subsidence rate of $166 \mathrm{ft}$ / 100,000 years in well NPR WO-2. The lowest rate, which disregards the prolonged hiatus attributed to uplift near the effective base of the aquifer in this well (table 3 ), is about 36 percent less than the previous (1994) estimated subsidence rate between the INEL and the Yellowstone Plateau; the highest rate, which accounts for the hiatus, is nearly identical to this rate.
The previous (1994) estimated subsidence rate is based on the assumption that differences between the average altitudes of rhyolite in wells NPR WO-2 and INEL \#1 at the INEL (fig. 3) and at the land surface on the Yellowstone Plateau are the result of subsidence during the past 4 million years (Smith and others, 1994). This assumption and the estimated rate, about $164 \mathrm{ft} / 100,000$ years, appear reasonable on the basis of the younger subsidence rate of $166 \mathrm{ft} / 100,000$ years estimated from accumulation rates in well NPR WO-2, the difference of 37 to 38 percent between apparent accumulation rates and subsidence rates estimated for young stratigraphic intervals at the INEL, and the difference of 38 percent between the average land-surface altitudes of the INEL and the Yellowstone Plateau. However, the previous (1994) estimated subsidence rate, which depends on geologic data from wells NPR WO-2 and INEL \#1 located in areas of reduced stratigraphic thickness related to past differential subsidence and uplift (figs. 2 and 3), is about 25 to 41 percent less than the average and maximum subsidence rates estimated for the INEL during the past 1.8 million years, about 220 to $280 \mathrm{ft} / 100,000$ years. If these higher rates were sustained anywhere at the INEL for the entire period, the resulting thickness of the stratigraphic section might be about 31 to 68 percent greater than that of $1,660 \mathrm{ft}$ in well NPR WO-2. This estimate is based on an accumulation time of 1.6 million years, the period of time represented by basalt-flow groups $\mathrm{AB}(10)$ and TU(1) (table 6), and apparent accumulation rates of 136 to $174 \mathrm{ft} / 100,000$ years that are 38 percent less than the average and maximum estimated subsidence rates. The greatest possible thickness of the stratigraphic section, estimated from the maximum apparent rate, is about 17 percent less than the thickness of the composite stratigraphic section below the accumulation datum, $3,371 \mathrm{ft}$ (figs. 7 and 8; table 4).

A slight reduction in the rate of subsidence during the past 350 thousand years was accompanied by an equal reduction of volcanism from about 200 to 350 thousand years ago and a near cessation of volcanism during the past 200 thousand years (fig. 7, line segment 1a). Basalt flows ranging in age from about 5 to 165 thousand years cover parts of the INEL and adjacent areas (Kuntz 
and others, 1994), but accumulation rates of these young rocks at the INEL were much less than the subsidence rate of about $192 \mathrm{ft} / 100,000$ years estimated for this period. Surficial deposits at the INEL mainly include young sediment (Anderson and others, 1996b) and basalt flows that were deposited more than 200 thousand years ago (Kuntz and others, 1994). As a result, most of the land surface at the INEL is part of a prolonged hiatus of large areal extent (table 3 ) that is related to a significant reduction in volcanism rather than structural processes. Similar volcanic hiatuses of such large areal extent and duration are not known to exist in older intervals of basalt and sediment at the INEL.

On the basis of accumulation rates, as much as 62 percent of the cumulative subsidence volume during the past 1.8 million years may have resulted from the mechanisms that controlled the withdrawal of basaltic magmas. This estimate is based on the short-term similarity of accumulation and subsidence rates in many areas of past volcanism and the long-term difference between these rates and maximum apparent accumulation rates at the INEL. At least 38 percent of the cumulative subsidence volume, now represented by the difference between the land-surface altitudes of the INEL and the Yellowstone Plateau, must have resulted from other mechanisms. Most of this volume probably resulted from isostatic adjustments related to the high-density mafic intrusion in the upper crust (Sparlin and others, 1982) and the added weight of accumulated basalt and sediment.

\section{SUMMARY}

Geologic ages and accumulation rates, estimated from regressions, were used to evaluate measured ages and interpreted stratigraphic and structural relations of basalt and sediment in the unsaturated zone and the Snake River Plain aquifer at the INEL in eastem Idaho. Geologic ages and accumulation rates were estimated from standard linear regressions of 21 mean $\mathrm{K}-\mathrm{Ar}$ ages, selected mean paleomagnetic ages, and cumulative depths of a composite stratigraphic section composed of complete intervals of basalt and sediment that were deposited in areas of past maximum subsidence. Accumulation rates also were estimated from regressions of stratigraphic intervals in wells USGS 80, NPR TEST, and PBF \#2 in and adjacent to an area of interpreted uplift at and near the ICPP and the TRA to allow a comparison of rates in areas of past uplift and subsidence.

Estimated geologic ages range from about 200 thousand to 1.8 million years before present and are reasonable approximations for the interval of basalt and sediment above the effective base of the aquifer, based on reported uncertainties of corresponding measured ages. Estimated ages between 200 and 800 thousand years are within the range of reported uncertainties for all $15 \mathrm{~K}-\mathrm{Ar}$ ages used in regressions and two out of three ${ }^{40} \mathrm{Ar} /{ }^{39} \mathrm{Ar}$ ages of duplicate samples. Two sets of estimated ages between 800 thousand and $1.8 \mathrm{mil}-$ lion years are within the range of reported uncertainties for all seven $\mathrm{K}$-Ar ages used in regressions, which include one shared age of about 800 thousand years. Two sets of ages were estimated for this interval because $\mathrm{K}$-Ar ages make up two populations that agree with previous (1979) and revised (1995) ages of three paleomagnetic subchrons. The youngest set of ages is consistent with a K-Ar age from the effective base of the aquifer that agrees with previous (1979) ages of the Olduvai Normal-Polarity Subchron. The oldest set of ages is consistent with an ${ }^{40} \mathrm{Ar} /{ }^{39} \mathrm{Ar}$ age of the same basalt flow that agrees with revised (1995) ages of the Olduvai Subchron. Regressions indicate that measured ages and stratigraphic interpretations are reasonable for basalt and sediment between the ages of 200 and 800 thousand years, the youngest deposits that could be evaluated using regressions. Regressions indicate potential errors in measured ages or stratigraphic interpretations for basalt and sediment between the ages of 800 thousand to 1.8 million years, the oldest deposits in the aquifer. Ages of older basalt flows in the aquifer are difficult to measure because many flows are altered. Stratigraphic relations of older basall and sediment in the aquifer are difficult to determine because there are few cored intervals of this age.

The stratigraphic section underlying the INEL is made up of overlapping intervals of basalt and 
sediment that accumulated in areas of past volcanism and subsidence. These areas covered hundreds of square miles, were active for periods ranging from 200 to 700 thousand years, shifted across a $1,000 \mathrm{mi}^{2}$ area during the past 1.8 million years, and were preceded and followed by periods of reduced accumulation. Periods of maximum accumulation in each area were accompanied by an approximate volumetric equilibrium between basaltic volcanism, accumulation, and subsidence. Pcriods of reduced accumulation in each area were accompanied by differential subsidence or uplift. As a result, the stratigraphic section is characterized by a succession of widespread stratigraphic intervals bounded by local offsets and hiatuses and differences in overall thickness as great as 100 percent. The section also is characterized by maximum long-term apparent accumulation rates that are about 38 percent less than past subsidence rates in areas of greatest thickness, a difference identical to that between the approximate average land-surface altitudes of the INEL and the Yellowstone Plateau, about 5,000 and $8,000 \mathrm{ft}$ above sea level, respectively.

Accumulation rates, estimated from regressions of stratigraphic intervals younger than 640 thousand years in wells USGS 80, NPR TEST, and PBF \#2 in and adjacent to the area of interpreted uplift at and near the ICPP and TRA, range from 59 to $282 \mathrm{ft} / 100,000$ years and average 163 $\mathrm{ft} / 100,000$ years, a rate that is nearly identical to the previous (1994) estimated subsidence rate between the INEL and the Yellowstone Plateau during the past 4 million years, about $164 \mathrm{ft} /$ 100,000 years. Accumulation rates estimated from regressions of the composite stratigraphic section, which is made up of stratigraphic intervals deposited in many areas of past subsidence for periods ranging from 200 to 700 thousand years during the past 1.8 million years, range from 171 to $270 \mathrm{ft} / 100,000$ years and average $218 \mathrm{ft} /$ 100,000 years, a rate that is 33 percent greater than the previous (1994) estimated subsidence rate. Although average accumulation rates in wells USGS 80, NPR TEST, and PBF \#2 agree with the previous (1994) estimated subsidence rate, the rates in wells USGS 80 and NPR TEST are apparent rates that are a relative measure of the difference between past rates of contemporan- eous subsidence and uplift, based on deep drillhole data. The best estimates of past subsidence rates range from about 160 to $280 \mathrm{ft} / 100,000$ years and average about $220 \mathrm{ft} / 100,000$ years, based on the previous (1994) estimated subsidence rate and accumulation rates unaffected by differential subsidence or uplift. Estimated subsidence rates averaged about $192 \mathrm{ft} / 100,000$ years and were much greater than accumulation rates during the past 200 thousand years, a period of greatly reduced volcanism. This interruption in basalt accumulation, which is unlike that of earlier periods and continues to the present day, includes most areas of the INEL.

On the basis of accumulation rates, subsidence probably resulted from the cumulative effects of several mechanisms that may have included crustal extension, thermal contraction, withdrawal of basaltic magmas, isostatic adjustments, and compaction of sediment and caldera deposits. Uplift proably resulted from the emplacement of lacoliths and domes within or beneath the subsiding stratigraphic section. As much as 62 percent of the cumulative subsidence volume during the past 1.8 million years may have resulted from the mechanisms that controlled the withdrawal of basaltic magmas. This estimate is based on the short-term similarity of accumulation and subsidence rates in many areas of past volcanism and the long-term difference between these rates and maximum apparent accumulation rates at the INEL. At least 38 percent of the cumulative subsidence volume, now represented by the difference between the land-surface altitudes of the INEL and the Yellowstone Plateau, must have resulted from other mechanisms. Most of this volume probably resulted from isostatic adjustments related to the high-density mafic intrusion in the upper crust and the added weight of accumulated basalt and sediment.

\section{REFERENCES CITED}

Anderson, S.R., 1991, Stratigraphy of the unsaturated zone and uppernost part of the Snake River Plain aquifer at the Idaho Chemical Processing Plant and Test Reactors Area, Idaho National Enginecring Laboratory, Idaho: U.S. Geological Survey Water- 
Resources Investigations Report 91-4010 (DOE/ ID-22095), $71 \mathrm{p}$.

Anderson, S.R., Ackerman, D.J., Liszewski, M.J., and Freiburger, R.M., 1996a, Stratigraphic data for wells at and near the Idaho National Engineering Laboratory, Idaho: U.S. Geological Survey WaterResources Investigations Report 96-248, (DOE/ ID-22127), 27 p., 1 diskette

Anderson, S.R., Liszewski, M.J., and Ackerman, D.J., 1996b, Thickness of surficial sediment at and near the Idaho National Engineering Laboratory, Idaho: U.S. Geological Survey Water-Resources Investigations Report 96-330, (DOE/ID-22128), 16 p.

Anderson, S.R., and Bartholomay, R.C., 1995, Use of natural-gamma logs and cores for determining stratigraphic relations of basalt and sediment at the Radioactive Waste Management Complex, Idaho National Engineering Laboratory, Idaho: Journal of the Idaho Academy of Science, v. 31, no. 1, p. 1-10.

Anderson, S.R., and Bowers, Beverly, 1995, Stratigraphy of the unsaturated zone and uppermost part of the Snake River Plain aquifer at Test Area North, Idaho National Engineering Laboratory, Idaho: U.S. Geological Survey Water-Resources Investigations Report 95-4130, (DOE/ID-22122) $47 \mathrm{p}$.

Anderson, S.R. and Lewis, B.D., 1989, Stratigraphy of the unsaturated zone at the Radioactive Waste Management Complex, Idaho National Engineering Laboratory, Idaho: U.S. Geological Survey Water-Resources Investigations Report 89-4065 (DOE/ID-22080), $54 \mathrm{p}$.

Bartholomay, R.C., Orr, B.R., Liszewski, M.J., and Jensen, R.G., 1995, Hydrologic conditions and distribution of selected radiochemical and chemical constituents in water, Snake River Plain aquifer, Idaho National Engineering Laboratory, Idaho, 1989 through 1991: U.S. Geological Survey Water-Resources Investigations Report 95-4175 (DOE/ID-22123), $47 \mathrm{p}$.

Berggren, W.A., Hilgen, F.J., Langereis, C.G., Kent, D.V., Obradovich, J.D., Raffi, I., Raymo, M.E., Shackleton, N.J., 1995, Late Neogene chronology: New perspectives in high-resolution stratigraphy: Geological Society of America Bulletin, v. 107, no. 11, p. 1,272-1,287.

Champion, D.E., Lanphere, M.A., and Kuntz, M.A., 1988, Evidence for a new geomagnetic reversal from lava flows in Idaho-discussion of short polarity reversals in the Brunhes and Late Matuyama Polarity Chrons: Journal of Geophysical Research, v. 93, no. B10, p. 11,677-11,680.

Davis, J.C., 1986, Statistics and data analysis in Geology, 2nd. ed.: John Wiley and Sons, New York, $646 \mathrm{p}$.

Doherty, D.J., McBroome, L.A., and Kuntz, M.A., 1979 , Preliminary geological interpretation and lithologic log of the exploratory geothermal test well (INEL-1), Idaho National Engineering Laboratory, Eastern Snake River Plain, Idaho: U.S. Geological Survey Open-File Report 79$1248,7 \mathrm{p}$.

Forman, S.L., Pierson, J., Smith, R.P., Hackett, W.R., and Valentine, G., 1994, Assessing the accuracy of thermoluminescence for dating baked sediments beneath late Quaternary lava flows, Snake River Plain, Idaho: Journal of Geophysical Research, v. 99, no. B8, p. 15,569-15,576.

Forman, S.L., Smith, R.P., Hackett, W.R., Tullis, J.A., and McDaniel, P.A., 1993, Timing of late Quaternary glaciations in the western United States based on the age of loess on the Eastern Snake River Plain, Idaho: Journal of Quaternary Research, $v$. 40, p. 30-37.

Fromm, J.M., Hackett, W.R., and Stephens, J.D., 1994, Primary mineralogy and alteration of basalts and sediments in drillcores from the Idaho National Engineering Laboratory, eastern Snake River Plain [Abs.]: International Symposium on the Observation of the Continental Crust Through Drilling, VIIth, Santa Fe, N. Mex., April 25-30, 1994, [Abstracts] unpaginated.

Hackett, W.R., Anders, M., and Walter, R.C., 1994, Preliminary stratigraphic framework of rhyolites from corehole WO-2, Idaho National Engineering Laboratory: Caldera-related, late-Tertiary silicic volcanism of the eastern Snake River Plain [Abs.]: International Symposium on the Observation of the Continental Crust Through Drilling, VIIth, Santa Fe, N. Mex., April 25-30, 1994, [Abstracts] unpaginated.

Iman, R.L., and Conover, W.J., 1983, A modern approach to statistics: John Wiley and sons, Inc, New York, 497 p.

Knobel, L.L., Cecil, L.D., and Wood, T.R., 1995, Chemical composition of selected core samples, Idaho National Engineering Laboratory, Idaho: U.S. Geological Survey Open-File Report 95-748, $59 \mathrm{p}$. 
Kuntz, M.A., Dalrymple, G.B., Champion, D.E., and Doherty, D.J., 1980, Petrography, age, and paleomagnetism of volcanic rocks at the Radioactive Waste Management Complex, Idaho National Engineering Laboratory, Idaho, with an evaluation of potential volcanic hazards: U.S. Geological Survey Open-File Report 80-388, 63 p.

Kuntz, M.A., Skipp, Betty, Lanphere, M.A., Scott, W.E., Pierce, K.L., Dalrymple, G.B., Champion, D.E., Embree, G.F., Page, W.R., Morgan, L.A., Smith, R.P., Hackett, W.R., and Rodgers, D.W., 1994, Gcologic map of the Idaho National Engineering Laboratory and adjoining areas, eastern Idaho: U.S. Geological Survey Miscellaneous Investigations Map I-2330, scale 1:100,000.

Lanphere, M.A., Champion, D.E., and Kuntz, M.A., 1993, Petrography, age, and paleomagnetism of basalt lava flows in coreholes Well 80, NRF 8904, NRF 89-05, and ICPP 123, Idaho National Engineering Laboratory, Idaho: U.S. Geological Survey Open-File Report 93-327, 40 p.

Lanphere, M.A., Kuntz, M.A., and Champion, D.E., 1994, Petrography, age, and paleomagnetism of basaltic lava flows in coreholes at Test Area North (TAN), Idaho National Engineering Laboratory: U.S. Geological Survey Open-File Report 94-686, $49 \mathrm{p}$.

Lawrence, R.F., and Hackett, W.R., 1994, Petrography and lithology of Tertiary rhyolites in WO-2 drillcore, Idaho National Engineering Laboratory (INEL), eastern Snake River Plain [Abs.]: International Symposium on the Observation of the Continental Crust Through Drilling, VIIth, Santa Fe, N. Mex., April 25-30, 1994, [Abstracts] unpaginated.

Mankinen, E.A., and Dalrymple, G.B., 1979, Revised geomagnetic polarity time scale for the interval 0.5 m.y. B.P.: Journal of Geophysical Research, v. 84, p. 615-626.

Pierce, K.L., and Morgan, L.A., 1992, The track of the Yellowstone hot spot: Volcanism, faulting, and uplift, in Link, P.K., Kuntz, M.A., and Platt, L.B., eds., Regional geology of eastern Idaho and western Wyoming: Geological Society of America Memoir 179, p. 1-53.

Reed, M.F., Bartholomay, R.C., and Hughes, S.S., 1996, Geochemistry and stratigraphic correlation of basalt lavas beneath the Idaho Chemical Processing Plant, Idaho National Engineering
Laboratory, Idaho: Environmental Geology, in press.

Shervais, John, Vetter; Scott, and Hackett, William, 1994, Chemical stratigraphy of basalts in coreholes NPR-E and WO-2, Idaho National Engineering Laboratory, Idaho-implications for plume dynamics in the Snake River Plain: International Symposium on the Observation of the Continental Crust Through Drilling, VIIth, Santa Fe, N. Mex., April 25-30, 1994, Proceedings, p. 93-96.

Smith, R.P., Hackett, W.R., Josten, N.E., Knutson, C.F., Jackson, S.M., Barton, C.A., Moos, D., Blackwell, D.D., and Kelley, S., 1994, Synthesis of deep drill hole information at the Idaho National Engineering Laboratory (INEL)-upper crustal environment in the continental track of a mantle hotspot: International Symposium on the Observation of the Continental Crust Through Drilling, VIIth, Santa Fe, N. Mex., April 25-30, 1994, Proceedings, p. 89-92.

Sparlin, M.A., Braile, L.W., and Smith, R.B., 1982, Crustal structure of the eastern Snake River Plain determined from ray-trace modeling of seismic refraction data: Journal of Geophysical Research, v. 87, p. 2,619-2,633.

Spiegel, M.R., 1975, Probability and Statistics: McGraw-Hill Book Company, New York, 372 p.

Whitehead, R.L., 1992, Geohydrologic framework of the Snake River Plain regional aquifer system, Idaho and eastern Oregon: U.S. Geological Survey Professional Paper 1408-B, 32 p., 6 pls. in pocket. 
Table 1. Selected cores and sources of data used to evaluate stratigraphic units underlying the Idaho National Engineering Laboratory

[Well is one from which continuous core was obtained (fig. 3). Depth is total depth of well and approximate total depth of core, in feet below land surface. Data include paleomagnetic inclination and polarity, K-Ar (potassium-argon) and ${ }^{40} \mathrm{Ar} /{ }^{39} \mathrm{Ar}(\operatorname{argon}-$ argon) ages, petrographic descriptions, and major-oxide and trace element chemistry. Symbol: -- indicates no data. Numbers in columns 3-6 indicate the following data references: $1=\mathrm{Kuntz}$ and others (1980); $2=$ Champion and others (1988); $3=\mathrm{Lanphere}$ and others (1993); $4=$ Lanphere and others (1994); $5=$ Knobel and others (1995); $6=$ Reed and others (1996); $7=$ Duane E. Champion, USGS, written commun., 1989-95; 8 = Marvin A. Lanphere, USGS, written commun., 1989-95; $9=$ Mel A. Kuntz, USGS, written commun., 1989-95; and 10 = Roy C. Bartholomay, written commun., 1989-95. Additional data for deposits in and underlying the Snake River Plain aquifer are indicated by the following references: $11=$ Shervais and others, $1994 ; 12=$ Lawrence and Hackett, 1994; and $13=$ Hackett and others, 1994]

\begin{tabular}{|c|c|c|c|c|c|}
\hline $\begin{array}{l}\text { Well and core } \\
\text { identifier }\end{array}$ & $\begin{array}{l}\text { Depth } \\
\text { (feet) }\end{array}$ & $\begin{array}{c}\text { Source of } \\
\text { paleomagnetic data }\end{array}$ & $\begin{array}{c}\text { Source of } \\
\text { geochronolngic } \\
\text { data }\end{array}$ & $\begin{array}{c}\text { Source of } \\
\text { petrographic data }\end{array}$ & $\begin{array}{l}\text { Source of chemical } \\
\text { data }\end{array}$ \\
\hline BG-76-1 & 228 & 1 & 1 & 1 & -- \\
\hline BG-77-1 & 600 & 1 & 1,2 & 1 & 10 \\
\hline$C-1 A$ & 1,805 & 7 & 8 & -- & - \\
\hline Corehole 1 & 2,002 & 7 & -- & -- & -- \\
\hline Corehole 2A & 3,000 & 7 & 8 & -- & -- \\
\hline DH-50 & 250 & 7 & $-\cdots$ & -- & -- \\
\hline GIN \#5 & 430 & 4 & -- & -- & -- \\
\hline GIN \#6 & 200 & 4 & - & -- & -- \\
\hline NPR TEST & 609 & 2 & 2 & -- & $5,10,11$ \\
\hline NPR WO-2 & 5,000 & 7,13 & 8,13 & 12 & 11 \\
\hline NRF \#6P & 500 & 7 & -- & -- & -- \\
\hline NRF \#7P & 500 & 7 & 8 & -- & -- \\
\hline NRF 89-04 & 248 & 3 & 3 & -- & -- \\
\hline NRF $89-05$ & 242 & 3 & 3 & 3 & -- \\
\hline PW-13 & 148 & 7 & -- & -- & - \\
\hline TCH \#1 & 600 & 4 & 4 & 4 & 5 \\
\hline TCH \#2 & 1,114 & 4 & 4 & 4 & 5 \\
\hline TRA 05 & 297 & 7 & 8 & -- & 5 \\
\hline USGS 80 & 204 & 3 & 3 & 3 & -- \\
\hline USGS 81 & 108 & 7 & -- & -- & -- \\
\hline USGS 93A & 233 & -- & -- & 1 & -- \\
\hline USGS 94 & 302 & 1 & 1 & 1 & -- \\
\hline USGS 118 & 570 & 7 & -- & -- & 10 \\
\hline USGS 121 & 746 & 7 & 8 & 9 & 6 \\
\hline USGS 123 & 744 & 3 & 3 & 3 & 6 \\
\hline WWW \#1 & 265 & 7 & -- & -- & -- \\
\hline
\end{tabular}


Table 2. Wells that penetrate the effective base of the Snake River Plain aquifer at the Idaho National Engineering Laboratory

[Depth is total depth of well, in feet below land surface. Base is the depth to the effective base of the Snake River Plain aquifer, in feet below land surface. Lithology indicates the relative abundance of basalt (B) and sediment (S) below the base of the aquifer to a depth of 500 feet; greatest abundance is listed first. Core indicates the availability of continuous core; see table 1]

\begin{tabular}{lcccc}
\multicolumn{1}{c}{ Well identifier } & Depth (feet) & Base (feet) & Lithology & Core \\
\hline C-1A & 1,805 & 1,710 & B, S & Yes \\
Corehole 2A & 3,000 & 846 & S, B & Yes \\
INEL \#1 & 10,365 & 965 & S, B & No \\
NPR WO-2 & 5,000 & 1,660 & B, S & Yes \\
S5G TEST & 1,276 & 884 & B, S & No \\
TCH \#2 & 1,114 & 883 & B, S & Yes \\
TRA \#4 & 970 & 909 & B, S & No \\
TRA DISP & 1,275 & 907 & B, S & No \\
USGS 7 & 1,200 & 895 & B, S & No \\
USGS 15 & 1,497 & 815 & S, B & No \\
\hline
\end{tabular}


Table 3. Prolonged hiatuses between basalt flows above the effective base of tie Snake River Plain aquifer in selected wells at the Idaho National Engineering Laboratory

[Well, C-1A, is a well that penetrates one or more hiatuses of at least 200 thousand years duration (fig. 3; table 1). Unit, D(1), is a basalt-flow group described by Anderson and others (1996a); single entry indicates that unit crops out or is overlain by sediment near the land surface. Depth, 41 (single entry), is the depth, in feet below land surface, to the youngest basalt-flow group in a well; depths, 279 and 287 (double entry), are depths to the base and top, respectively, of two basalt-flow groups that differ in age by more than 200 thousand years. Measured age, 218, is the mean age of a unit, in thousands of years before present from table 6; age in brackets, [230]. is mean age or pooled mean age reported by Kuntz and others (1980). Estimated age, 198, is mean age that was estimated for a unit in the composite stratigraphic section (figs. 7 and 8; table 6); age in brackets, [290], is mean age that was estimated for a unit not in the composite section. Line segments, la through $3 \mathrm{c}$, correspond to line segments in figures 7 and 8 and table 5 . Hiatus, 198, is the length of elapsed time, in thousands of years, since the last basalt flow or between two basalt flows in a weli; time determined from [measured] and estimated mean ages. Symbol, --, indicates no data]

\begin{tabular}{|c|c|c|c|c|c|c|c|}
\hline Well identifier & Unit & Depth (feet) & $\begin{array}{l}\text { Measured } \\
\text { age } \\
\text { (thousands } \\
\text { of years) }\end{array}$ & $\begin{array}{l}\text { Estimated } \\
\text { age } \\
\text { (thousands } \\
\text { of years) }\end{array}$ & $\begin{array}{c}\text { Line } \\
\text { segment }\end{array}$ & $\begin{array}{c}\text { Hiatus } \\
\text { (thousands } \\
\text { of years) }\end{array}$ & Core \\
\hline NPR TEST & $\mathrm{AB}(10)$ & 0 & 218 & 198 & $1 \mathrm{a}$ & [218], 198 & Yes \\
\hline QAB & $\begin{array}{l}C(1) \\
D E \text { 6-7(1) }\end{array}$ & $\begin{array}{l}194 \\
194\end{array}$ & [211] & $\begin{array}{l}{[270]} \\
{[476]}\end{array}$ & $\begin{array}{l}1 \mathrm{a} \\
1 \mathrm{~b}\end{array}$ & 206 & No \\
\hline BG-77-1 & $\begin{array}{l}D(1) \\
E(1)\end{array}$ & $\begin{array}{l}279 \\
287\end{array}$ & $\begin{array}{r}{[230]} \\
515\end{array}$ & $\begin{array}{r}{[290]} \\
512\end{array}$ & $\begin{array}{l}1 \mathrm{a} \\
1 \mathrm{~b}\end{array}$ & {$[285], 212$} & Yes \\
\hline$C-1 A$ & $\begin{array}{l}\mathrm{Q}(2) \\
\mathrm{T}(2)\end{array}$ & $\begin{array}{l}1,710 \\
1,710\end{array}$ & -- & $\begin{array}{r}{[1,480]} \\
1,773\end{array}$ & $\begin{array}{l}3 b \\
3 b\end{array}$ & 293 & Yes \\
\hline USGS 80 & $\mathrm{DE} 4-5(3)$ & 41 & 419 & [430] & $1 b$ & [419], 430 & Yes \\
\hline C-1A & $\begin{array}{l}\mathrm{H}(1) \\
\mathrm{LM}(8)\end{array}$ & $\begin{array}{l}698 \\
703\end{array}$ & $\begin{array}{r}619 \\
--\end{array}$ & $\begin{array}{r}619 \\
1,060\end{array}$ & $\begin{array}{l}1 \mathrm{c} \\
3 \mathrm{a}\end{array}$ & 441 & Yes \\
\hline NPR WO-2 & $\begin{array}{l}\mathrm{N}(4) \\
\mathrm{TU}(1)\end{array}$ & $\begin{array}{l}1,660 \\
1,696\end{array}$ & 1,865 & $\begin{array}{l}1,205 \\
1,790\end{array}$ & $\begin{array}{l}3 b \\
3 c\end{array}$ & 585 & Yes \\
\hline TRA DISP & $\begin{array}{l}\text { LM1(1) } \\
\text { TU(1) }\end{array}$ & $\begin{array}{l}897 \\
907\end{array}$ & $\begin{array}{r}-- \\
1,865\end{array}$ & $\begin{array}{r}800 \\
1,790\end{array}$ & $\begin{array}{l}3 a \\
3 c\end{array}$ & 990 & No \\
\hline TCH \#2 & $M(1)$ & 40 & -- & {$[1,080]$} & $3 b$ & 1,080 & Yes \\
\hline
\end{tabular}


Table 4. Sites used to construct a composite stratigraphic section of selected basalt-flow groups and sedimentary interbeds in the unsaturated zone and the Snake River Plain aquifer at the Idaho National Engineering Laboratory

[Sites, A through J, indicate wells and datums used to construct line segments 1a through $3 \mathrm{c}$ in figures 7 and 8 . Wells include selected wells from the stratigraphic data base described by Anderson and others (1996a). Altitude is the land surface altitude at each well, in feet above sea level. Depth indicates the depth or depth interval of a site, in feet below land surface. Cumulative depth indicates the depth or depth interval of a site, in feet below the subsidence datum; interval for site B (fig. 7, line segment 1a) indicates the difference in land-surface altitude, 380 feet, between the subsidence datum, site $A$, and the accumulation datum, site $\mathrm{C}$. Units, $\mathrm{AB}(10)$ through $\mathrm{TU}(1)$, are selected basalt-flow groups and sedimentary interbeds from Anderson and others (1996a). Altitude, depth, and cumulative depth are rounded to the nearest foot and are accurate \pm 2 feet]

\begin{tabular}{llccccl}
\hline Site & Well identifier & $\begin{array}{c}\text { Altitude } \\
\text { (feet) }\end{array}$ & Depth (feet) & $\begin{array}{c}\text { Cumulative depth } \\
\text { (feet) }\end{array}$ & Core & Datums and units \\
\hline A & Butte City \#2 & 5,315 & 0 & 0 & No & Subsidence datum \\
B & & & & $0-380$ & & No accumulation \\
C & NPR TEST & 4,935 & 0 & 380 & Yes & Accumulation datum \\
D & AREA II & 5,130 & $6-524$ & $380-898$ & No & AB(10) through DE5(1) \\
E & PBF \#2 & 4,924 & $323-800$ & $898-1,375$ & No & DE5(1) through H(1) \\
F & QAB & 5,190 & $770-1,087$ & $1,375-1,692$ & No & H(1) through L(1) \\
G & NPR WO-2 & 4,930 & $767-1,660$ & $1,692-2,585$ & Yes & L(1) through NO(1) \\
H & C-1A & 5,029 & $1,074-1,477$ & $2,585-2,988$ & Yes & NO(1) through P(3) \\
I & TCH \#2 & 4,792 & $120-883$ & $2,988-3,751$ & Yes & P(1) through S5(1) \\
J & NPR WO-2 & 4,930 & $1,660-1,696$ & $3,751-3,787$ & Yes & T(2) through TU(1), effective \\
& & & & & & base of aquifer \\
\hline
\end{tabular}


Table 5. Line segments and regressions used to estimate geologic ages and maximum accumulation/subsidence rates of selected basalt-flow groups and sedimentary interbeds in the unsaturated zone and the Snake River Plain aquifer at the Idaho National Engineering Laboratory

[Line segments, 1a through 3c, correspond to line segments in figures 7 and 8 and table 6. Age, in thousands of years before present, is the dependent variable in each regression equation for the age interval shown. Cumulative depth, in feet below the subsidence datum (table 4), is the independent variable in each regression equation for the depth interval shown. Correlation coefficient of 1.0000 indicates that regression equation is based on average or selected end points; coefficient of less than 1.0000 indicates that equation is based on selected measured ages. Regression equation indicates that age equals the cumulative depth multiplied by the computed siope plus or minus the computed intercept. Rate of accumulation/subsidence indicates the average rate of accumulation and subsidence at sites in table 4 for the age intervals shown, in feet per hundred thousand years (ft/100 Ky); rates in brackets indicate that accumulation did not occur at sites during the past 200 thousand years. Age and depth control, numbers 1 through $57 \mathrm{~b}$, correspond to numbered ages and cumulative depths in figures 7 and 8 and table 6; numbers indicate the ages and cumulative depths used in each regression. Cumulative depths are rounded to the nearest foot and are accurate to \pm 2 feet]

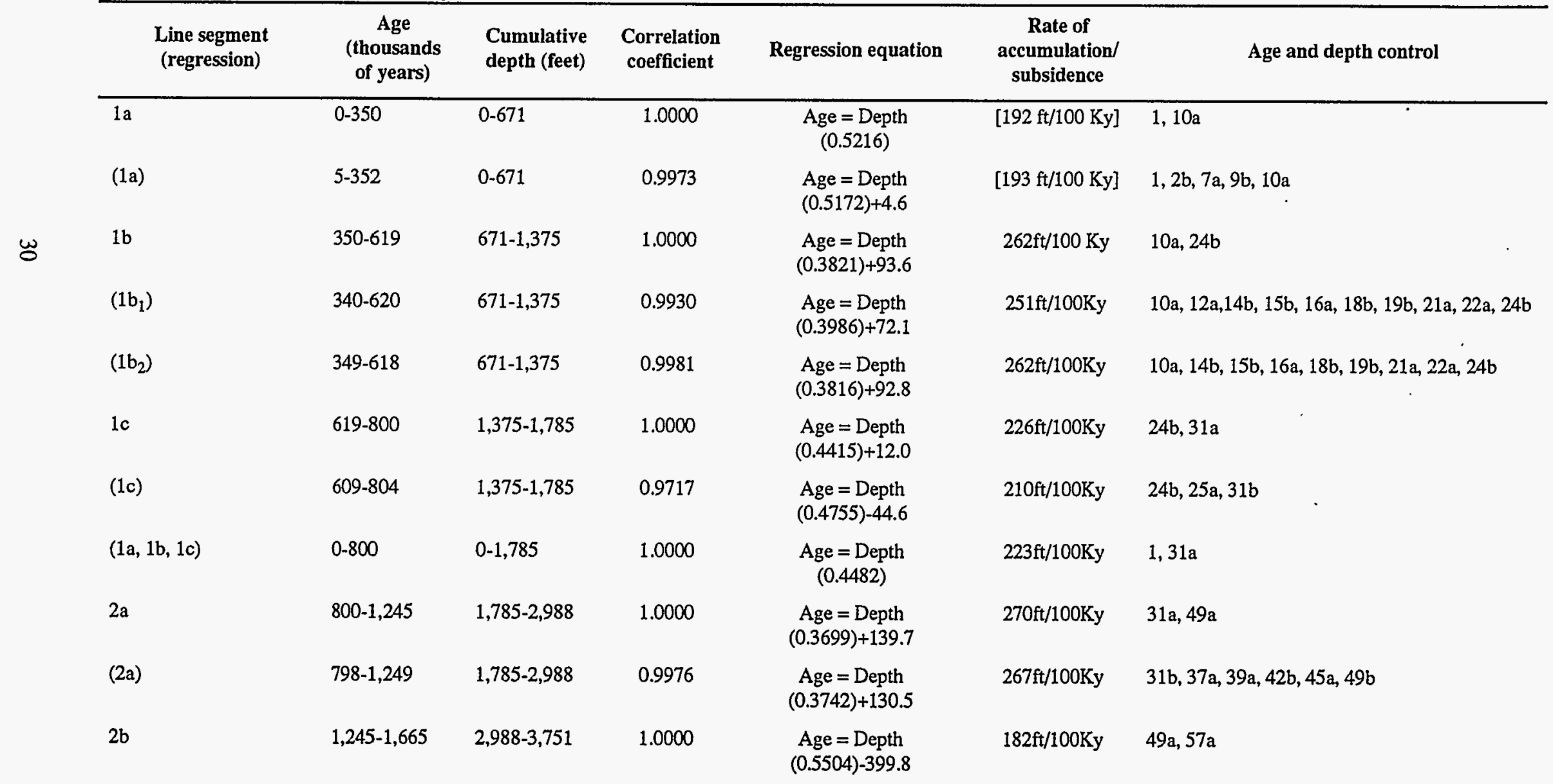


Table 5. Line segments and regressions used to estimate geologic ages and maximum accumulation/subsidence rates of selected basalt-flow groups and sedimentary interbeds in the unsaturated zone and the Snake River Plain aquifer at the Idaho National Engineering Laboratory-Continued

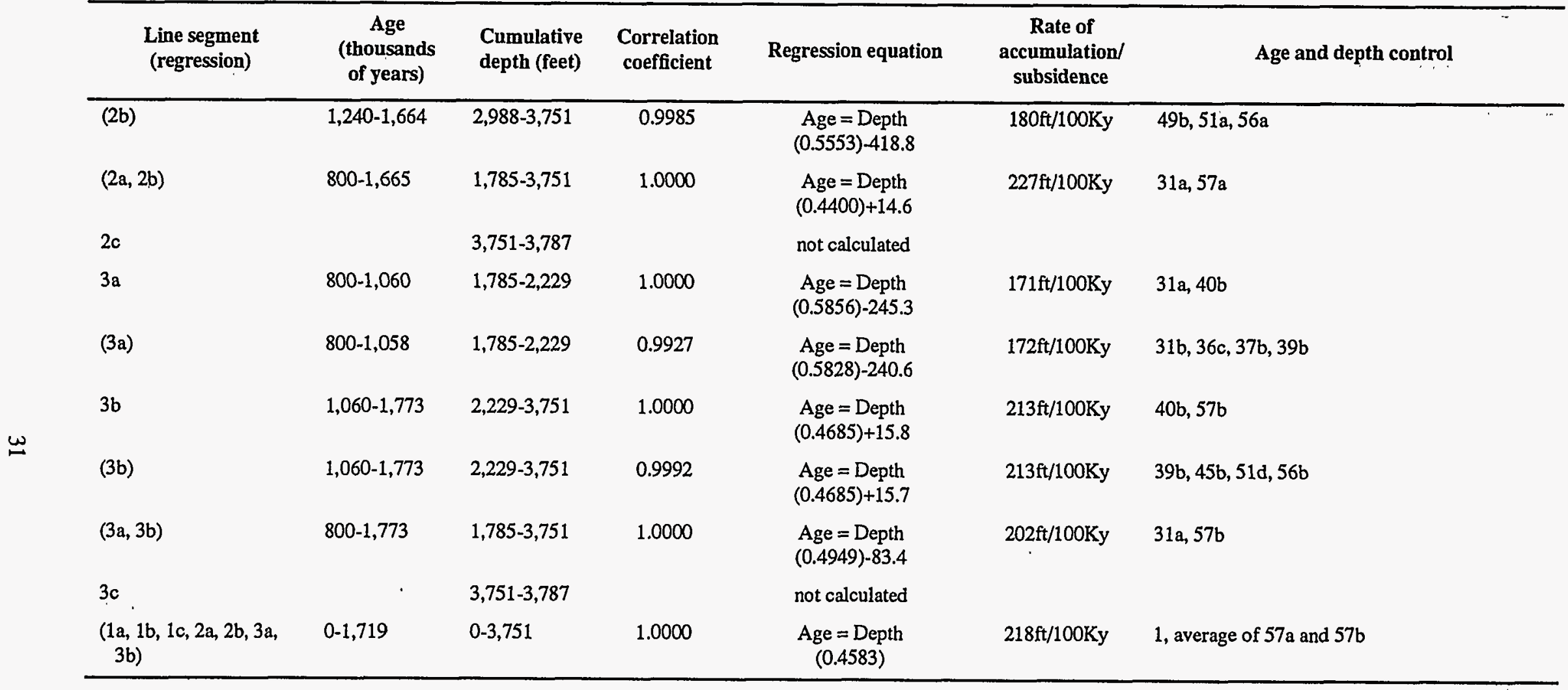


Table 6. Measured and estimated geologic ages of selected basalt-flow groups and sedimentary interbeds in the unsaturated zone and the Snake River Plain aquifer at the Idaho National Engineering Laboratory

[Numbers, 1 through 58d, correspond to ages and cumulative depths shown in figures 7 and 8 . Units, $A B(10)$ through $T U(1)$, are selected basalt-flow groups and sedimentary interbeds from Anderson and others (1996a). Information in brackets between units indicates the following paleomagnetic chrons and subchrons described by Mankinen and Dalrymple (1979), Champion and others (1988), and Berggren and others (1995): BL $=B$ ig Lost; $B / M=B$ runhes/Matuyama boundary; $J(T)=$ top of the Jaramillo; $J(B)=$ bottom of the Jaramillo; $C(T)=$ top of the Cobb Mtn.; $C(M)=$ middle of the Cobb $M t n . ; C(B)=$ bottom of the Cobb Mtn.; and $O(T)=$ top of the Olduvai. Measured ages, $218 \pm 49$ to $<1,865 \pm 24>$, include the following categories of ages, in thousands of years before present: $218 \pm 49=\mathrm{K}$-Ar age reported by Champion and others (1988), Lanphere and others (1993), Lanphere and others (1994), or Kuntz and others (1994); 1,210 = age of paleomagnetic chron or subchron; [982 \pm 53 ] = unpublished K-Ar age that disagrees with revised (1995) ages of paleomagnetic subcron (M.A. Lanphere, USGS, written commun., 1992); and $<619 \pm 22>=$ unpublished ${ }^{40} \mathrm{Ar} /{ }^{39} \mathrm{Ar}$ age that agrees with previous K-Ar age or revised (1995) ages of paleomagnetic subchron (M.A. Lanphere, USGS, written commun., 1994-95). Ages followed by (Y) were used for regressions; ages followed by (N) were not used for regressions (table 5). Estimated ages interpolated from line segments $1 \mathrm{a}, 1 \mathrm{~b}, 1 \mathrm{c}, 2 \mathrm{a}, 2 \mathrm{~b}, 3 \mathrm{a}$, and $3 \mathrm{~b}$ in figures 7 and 8 and table 5; ages in parentheses are estimated mean ages of paleomagnetic chron or subchron. Paleomagnetic polarity is indicated by the following symbols: $N=$ normal; $R=\operatorname{reversed;} N / R=$ older unit(s) reversed; $R / N=$ older unit(s) normal; $N$ or $R=$ polarity of basalt core or outcrop; $(N)$ or $(R)=$ probable polarity of basalt in well that was not cored; $[N]$ or $[R]=$ probable polarity of sediment; and $<\mathrm{N}>=$ basalt that cooled during an $\mathrm{R} / \mathrm{N}$ reversal. Site indicates well, core, or outcrop where ages of units were measured or estimated (figure 3; table 4). Depth indicates the depth, in feet below land surface, to the top of a unit in a well for which ages were estimated. Depth also indicates the depth or depth interval of a core sample for which ages were measured; $S$, indicates surficial samples. Cumulative depth (table 4) corresponds to the top of a unit or units in figures 7 and 8 . Line segment corresponds to a line segment in figures 7 and 8 and table 5. Depth and cumulative depth are rounded to the nearest foot and are accurate to \pm 2 feet. Age uncertainties are reported standard deviations of measured ages and calculated standard errors of estimated ages; uncertainties of paleomagnetic ages not reported or estimated. Large differences between measured and estimated ages, such as for numbers $52,53,54$, and 55 , indicate areas that need additional study.]

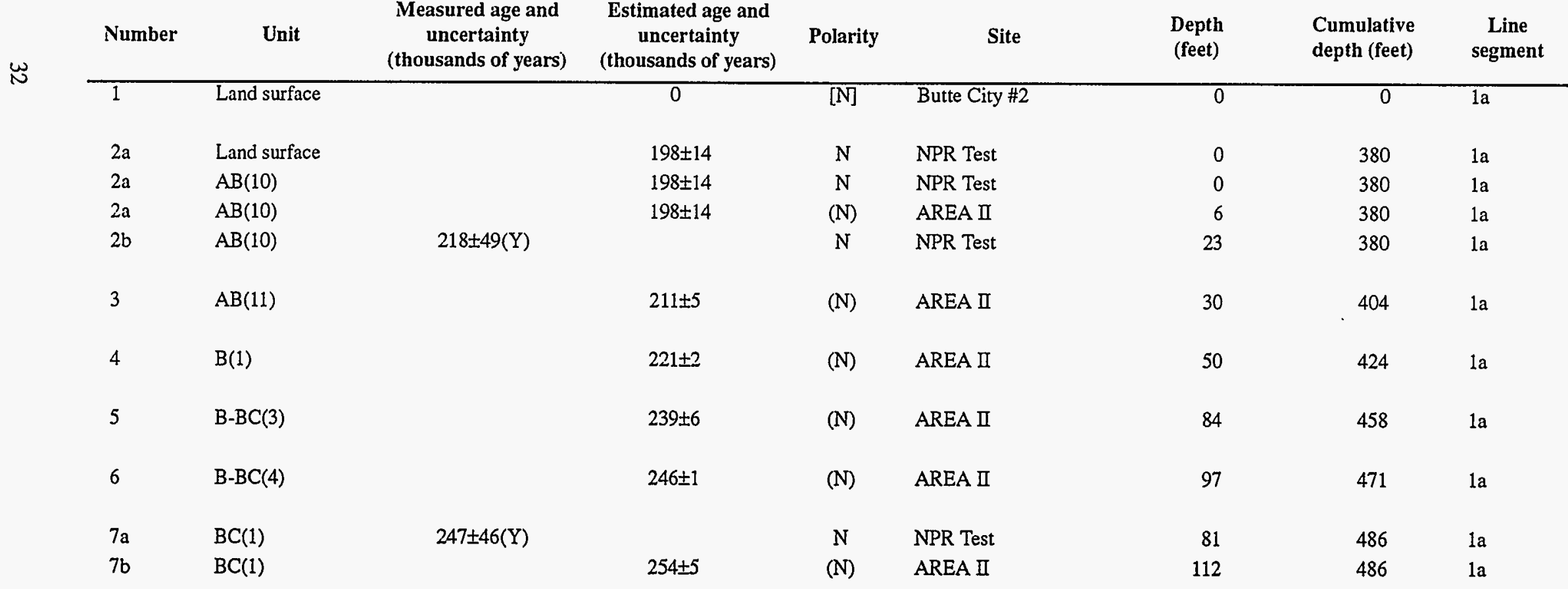


Table 6. Measured and estimated geologic ages of selected basalt-flow groups and sedimentary interbeds in the unsaturated zone and the Snake River Plain aquifer at the Idaho National Engineering Laboratory-Continued

\begin{tabular}{|c|c|c|c|c|c|c|c|c|}
\hline Number & Unit & $\begin{array}{l}\text { Measured age and } \\
\text { uncertainty } \\
\text { (thousands of years) }\end{array}$ & $\begin{array}{l}\text { Estimated age and } \\
\text { uncertainty } \\
\text { (thousands of years) }\end{array}$ & Polarity & Site & $\begin{array}{l}\text { Depth } \\
\text { (feet) }\end{array}$ & $\begin{array}{l}\text { Cumulative } \\
\text { depth (feet) }\end{array}$ & $\begin{array}{c}\text { Line } \\
\text { segment }\end{array}$ \\
\hline 8 & $C D(1)$ & & $285 \pm 13$ & $(\mathrm{~N})$ & AREA II & 172 & 546 & 1a \\
\hline $9 a$ & $D(4)$ & & $302 \pm 1$ & $(\mathrm{~N})$ & AREA II & 206 & 580 & 1a \\
\hline $9 \mathrm{~b}$ & $\mathrm{DE} 1(2)$ & $303 \pm 30(Y)$ & & $\mathrm{N}$ & NRF 89-05 & 79 & 580 & 1a \\
\hline $10 \mathrm{a}$ & $\mathrm{DE} 2(1)$ & $350 \pm 40(Y)$ & & $\mathrm{N}$ & NPR Test & 157 & 671 & $1 a, b$ \\
\hline $10 \mathrm{~b}$ & $\mathrm{DE} 2(1)$ & & $350 \pm 0$ & $(\mathrm{~N})$ & AREA II & 297 & 671 & $1 \mathrm{a}, \mathrm{b}$ \\
\hline 11 & DE3(1) & & $362 \pm 3$ & $(\mathrm{~N})$ & AREA II & 328 & 702 & $1 b$ \\
\hline $12 \mathrm{a}$ & DE3-4(1) & $358 \pm 46(N)$ & & $\mathrm{N}$ & Radio Facility Butte & $S$ & 781 & $1 b$ \\
\hline $12 b$ & DE3-4(1) & & $392 \pm 19$ & $(\mathrm{~N})$ & AREA II & 407 & 781 & $1 b$ \\
\hline 13 & DE3-4(3) & & $406 \pm 9$ & $(\mathrm{~N})$ & AREA II & 445 & 819 & $1 b$ \\
\hline $14 \mathrm{a}$ & $\mathrm{DEA}(1)$ & & $424 \pm 4$ & $(\mathrm{~N})$ & AREA II & 491 & 865 & $1 b$ \\
\hline $14 b$ & DE4-5(3) & $419 \pm 33(Y)$ & & $\mathrm{N}$ & USGS 80 & 51 to 55 & 865 & $1 \mathrm{~b}$ \\
\hline $15 \mathrm{a}$ & DE5(1) & & $437 \pm 3$ & $(N)$ & AREA II & 524 & 898 & $1 \mathrm{~b}$ \\
\hline $15 a$ & DE5(1) & & $437 \pm 3$ & $(\mathrm{~N})$ & PBF \#2 & 323 & 898 & $1 \mathrm{~b}$ \\
\hline $15 b$ & DE5(1) & $441 \pm 77(\mathrm{Y})$ & & $\mathrm{N}$ & NPR Test & 352 & 898 & $1 \mathrm{~b}$ \\
\hline $16 a$ & DE5-6(1) & $461 \pm 24(Y)$ & & $N$ & USGS 80 & 99 to 127 & 993 & $1 \mathrm{~b}$ \\
\hline $16 \mathrm{~b}$ & DE6(1) & & $473 \pm 8$ & $(\mathrm{~N})$ & PBF \#2 & 418 & 993 & $1 b$ \\
\hline 17 & DE7(1) & & $479 \pm 8$ & $(\mathrm{~N})$ & PBF \#2 & 433 & 1,008 & $1 b$ \\
\hline $18 a$ & DE8(1) & & $488 \pm 2$ & $(\mathrm{~N})$ & PBF \#2 & 456 & 1,031 & $1 b$ \\
\hline $18 \mathrm{~b}$ & DE8(1) & $491 \pm 80(Y)$ & & $\mathrm{N}$ & NPR Test & 444 & 1,031 & $1 b$ \\
\hline $19 a$ & $E(1)$ & & $512 \pm 2$ & $(\mathrm{~N})$ & PBF\#2 & 519 & 1,094 & $1 b$ \\
\hline $19 b$ & $E(1)$ & $515 \pm 85(Y)$ & & $\mathrm{N}$ & BG-77-1 & 300 to 329 & 1,094 & $1 b$ \\
\hline
\end{tabular}


Table 6. Measured and estimated geologic ages of selected basalt-flow groups and sedimentary interbeds in the unsaturated zone and the Snake River Plain aquifer at the Idaho National Engineering Laboratory-Continued

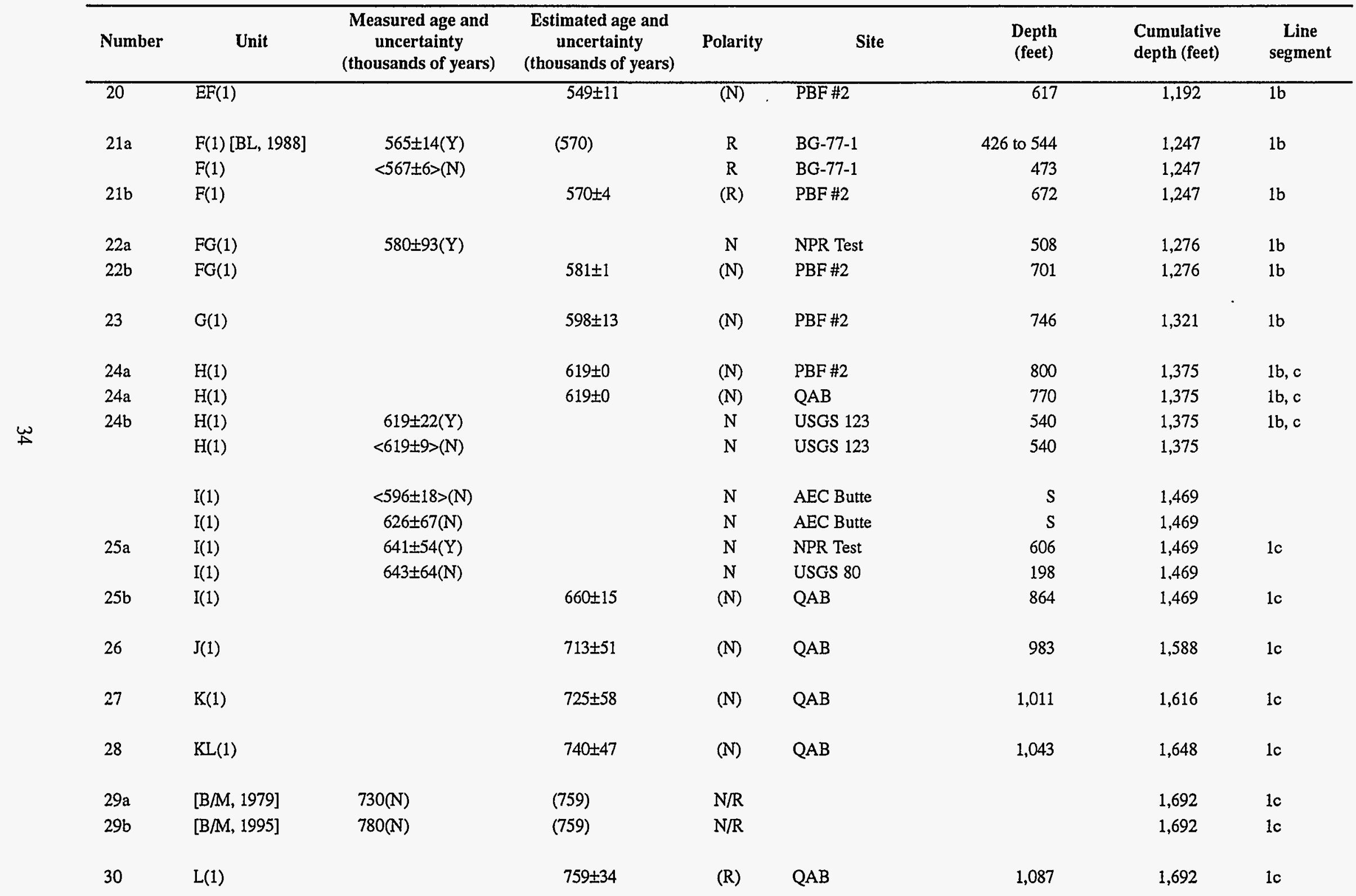


Table 6. Measured and estimated geologic ages of selected basalt-flow groups and sedimentary interbeds in the unsaturated zone and the Snake River Plain aquifer at the Idaho National Engineering Laboratory-Continued

\begin{tabular}{|c|c|c|c|c|c|c|c|c|}
\hline Number & Unit & $\begin{array}{l}\text { Measured age and } \\
\text { uncertainty } \\
\text { (thousands of years) }\end{array}$ & $\begin{array}{l}\text { Estimated age and } \\
\text { uncertainty } \\
\text { (thousands of years) }\end{array}$ & Polarity & Site & $\begin{array}{l}\text { Depth } \\
\text { (feet) }\end{array}$ & $\begin{array}{l}\text { Cumulative } \\
\text { depth (feet) }\end{array}$ & $\begin{array}{c}\text { Line } \\
\text { segment }\end{array}$ \\
\hline 30 & $\overline{L(1)}$ & & $759 \pm 34$ & $\overline{\mathrm{R}}$ & NPR WO-2 & 767 & 1,692 & $1 \mathrm{c}$ \\
\hline $31 a$ & LM1(1) & & $800 \pm 5$ & [R] & NPR WO-2 & 860 & 1,785 & $1 c, 2 a, 3 a$ \\
\hline $31 \mathrm{~b}$ & LM1(4) & $807 \pm 33(Y)$ & & $\mathrm{R}$ & Richard Butte & $S$ & 1,785 & $1 c, 2 a, 3 a$ \\
\hline$\ldots$ & $-\ldots$ & - & מ & -...- - - & 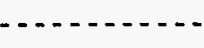 & $\cdots$ & - & 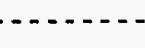 \\
\hline $31 \mathrm{a}$ & LM1(1) & & $800 \pm 5$ & {$[\mathrm{R}]$} & NPR WO-2 & 860 & 1,785 & $1 c, 2 \mathrm{a}$ \\
\hline $31 b$ & LM1(4) & $807 \pm 33(Y)$ & & $\mathrm{R}$ & Richard Butte & $S$ & 1,785 & $1 c, 2 a$ \\
\hline $32 a$ & LM2(1) & & $813 \pm 4$ & $\mathrm{R}$ & NPR WO-2 & 896 & 1,821 & $2 a$ \\
\hline $33 a$ & $\operatorname{LM} 3(1)$ & & $824 \pm 12$ & $\mathrm{R}$ & NPR WO-2 & 925 & 1,850 & $2 a$ \\
\hline $34 \mathrm{a}$ & LM4(1) & & $853 \pm 32$ & $\mathrm{R}$ & NPR WO-2 & 1,003 & 1,928 & $2 a$ \\
\hline $35 a$ & LM5(1) & & $877 \pm 16$ & $\mathrm{R}$ & NPR WO-2 & 1,068 & 1,993 & $2 a$ \\
\hline $36 a$ & LM6(1) & & $900 \pm 0$ & $\mathrm{R}$ & NPR WO-2 & 1,131 & 2,056 & $2 a$ \\
\hline $37 \mathrm{a}$ & [J(T), 1979] & $900(Y)$ & (921) & $\mathrm{R} / \mathrm{N}$ & & & 2,112 & $2 a$ \\
\hline $38 a$. & LM7(1) & & $921 \pm 15$ & $\langle N\rangle$ & NPR WO-2 & 1,187 & 2,112 & $2 a$ \\
\hline $39 a$ & {$[\mathrm{~J}(\mathrm{~B}), 1979]$} & $970(Y)$ & (964) & $N / R$ & & & 2,229 & $2 a$ \\
\hline $40 a$ & LM8(1) & & $964 \pm 4$ & $\mathrm{R}$ & NPR WO-2 & 1,304 & 2,229 & $2 a$ \\
\hline $41 \mathrm{a}$ & $\mathrm{M}(2)$ & & $999 \pm 20$ & $\mathrm{R}$ & NPR WO-2 & 1,397 & 2,322 & $2 a$ \\
\hline $42 a$ & $\mathrm{~N}(1)$ & & $1,037 \pm 5$ & $\mathrm{R}$ & NPR WO-2 & 1,502 & 2,427 & $2 a$ \\
\hline $42 b$ & $N(1)$ & $1,044 \pm 35(Y)$ & & $\mathrm{R}$ & $\mathrm{TCH} \# 1$ & 87 & 2,427 & $2 a$ \\
\hline $43 a$ & $N(3)$ & & $1,060 \pm 11$ & $\mathrm{R}$ & NPR WO-2 & 1,564 & 2,489 & $2 a$ \\
\hline $44 \mathrm{a}$ & $N(4)$ & & $1,079 \pm 15$ & $\mathrm{R}$ & NPR WO-2 & 1,614 & 2,539 & $2 a$ \\
\hline
\end{tabular}


Table 6. Measured and estimated geologic ages of selected basalt-flow groups and sedimentary interbeds in the unsaturated zone and the Snake River Plain aquifer at the Idaho National Engineering Laboratory-Continued

\begin{tabular}{|c|c|c|c|c|c|c|c|c|}
\hline Number & Unit & $\begin{array}{c}\text { Measured age and } \\
\text { uncertainty } \\
\text { (thousands of years) }\end{array}$ & $\begin{array}{l}\text { Estimated age and } \\
\text { uncertainty } \\
\text { (thousands of years) }\end{array}$ & Polarity & Site & $\begin{array}{l}\text { Depth } \\
\text { (feet) }\end{array}$ & $\begin{array}{l}\text { Cumulative } \\
\text { depth (feet) }\end{array}$ & $\begin{array}{c}\text { Line } \\
\text { segment }\end{array}$ \\
\hline $45 a$ & {$[\mathrm{C}(\mathrm{M}), 1979]$} & $1,100(Y)$ & $(1,096)$ & $\mathrm{R} / \mathrm{N}$ & & & 2,585 & $2 a$ \\
\hline $46 a$ & $\mathrm{NO}(1)$ & & $1,096 \pm 3$ & $(\mathrm{~N})$ & NPR WO-2 & 1,660 & 2,585 & $2 a$ \\
\hline $46 a$ & $\mathrm{NO}(1)$ & & $1,096 \pm 3$ & $N$ & $\mathrm{C}-1 \mathrm{~A}$ & 1,074 & 2,585 & $2 \mathrm{a}$ \\
\hline $48 \mathrm{a}$ & $\mathrm{O}(1)$ & & $1,215 \pm 23$ & {$[R]$} & $\mathrm{C}-1 \mathrm{~A}$ & 1,396 & 2,907 & $2 a$ \\
\hline $49 a$ & $\mathrm{P}(3)$ & & $1,245 \pm 2$ & $\mathrm{R}$ & $C-1 \mathrm{~A}$ & 1,477 & 2,988 & $2 a, b$ \\
\hline $49 a$ & $\mathrm{P}(1)$ & & $1,245 \pm 2$ & $\mathrm{R}$ & $\mathrm{TCH} \# 2$ & 120 & 2,988 & $2 a, b$ \\
\hline $49 b$ & $P(1)$ & $1,248 \pm 69(Y)$ & & $\mathrm{R}$ & $\mathrm{TCH} \# 1$ & 175 & 2,988 & $2 a, b$ \\
\hline $50 \mathrm{a}$ & $Q(1)$ & & $1,314 \pm 47$ & $\mathrm{R}$ & $\mathrm{TCH} \# 2$ & 246 & 3,114 & $2 b$ \\
\hline $51 \mathrm{a}$ & $\mathrm{R} 1(1)$ & $1,412 \pm 47(\mathrm{Y})$ & & $\mathrm{R}$ & $\mathrm{TCH} \# 2$ & 467 & 3,321 & $2 b$ \\
\hline $51 \mathrm{~b}$ & $\mathrm{R} 1(1)$ & & $1,428 \pm 11$ & $\mathrm{R}$ & $\mathrm{TCH} \# 2$ & 453 & 3,321 & $2 \mathrm{~b}$ \\
\hline \multirow[t]{2}{*}{$52 \mathrm{a}$} & $\mathrm{R} 2(1)$ & & $1,439 \pm 19$ & $\mathrm{R}$ & $\mathrm{TCH} \# 2$ & 473 & 3,341 & $2 b$ \\
\hline & $\mathrm{R} 2(1)$ & $2,053 \pm 79(\mathrm{~N})$ & & $\mathrm{R}$ & $\mathrm{TCH} \# 2$ & 534 & 3,341 & $2 b$ \\
\hline \multirow[t]{2}{*}{$53 a$} & S1(1) & & $1,482 \pm 49$ & $\mathrm{R}$ & $\mathrm{TCH} \# 2$ & 551 & 3,419 & $2 \mathrm{~b}$ \\
\hline & S1(1) & $1,936 \pm 83(\mathrm{~N})$ & & $\mathrm{R}$ & $\mathrm{TCH} \# 1$ & 523 & 3,419 & $2 b$ \\
\hline \multirow[t]{2}{*}{$54 a$} & $S 2(1)$ & & $1,517 \pm 74$ & $\mathrm{R}$ & TCH \#2 & 615 & 3,483 & $2 \mathrm{~b}$ \\
\hline & S2(1) & $2,115 \pm 46(\mathrm{~N})$ & & $\mathrm{R}$ & $\mathrm{TCH} \# 2$ & 637 & 3,483 & \\
\hline \multirow[t]{2}{*}{$55 \mathrm{a}$} & S5(1) & & $1,588 \pm 58$ & $\mathrm{R}$ & TCH \#2 & 743 & 3,611 & $2 b$ \\
\hline & S5(1) & $2,556 \pm 35(\mathrm{~N})$ & & $\mathrm{R}$ & $\mathrm{TCH} \# 2$ & 785 & 3,611 & $2 b$ \\
\hline \multicolumn{2}{|c|}{ Effective base of aquifer } & & & $\mathrm{R}$ & $\mathrm{TCH} \# 2$ & 883 & 3,751 & $2 b, c$ \\
\hline \multicolumn{2}{|c|}{ Effective base of aquifer } & & & $\mathrm{R}$ & NPR WO-2 & 1,660 & 3,751 & $2 b, c$ \\
\hline $56 a$ & {$[\mathrm{O}(\mathrm{T}), 1979]$} & $1,670(Y)$ & $(1,665)$ & $R / N$ & & & 3,751 & $2 b, c$ \\
\hline $57 \mathrm{a}$ & $\mathrm{T}(2)$ & & $1,665 \pm 11$ & {$[\mathrm{~N}]$} & NPR WO-2 & 1,660 & 3,751 & $2 b, c$ \\
\hline $58 \mathrm{a}$ & $T U(1)$ & {$[1,681 \pm 40](\mathbb{N})$} & & $N$ & NPR WO-2 & 1,708 & 3,787 & $2 c$ \\
\hline
\end{tabular}


Table 6. Measured and estimated geologic ages of selected basalt-flow groups and sedimentary interbeds in the unsaturated zone and the Snake River Plain aquifer at the Idaho National Engineering Laboratory-Continued

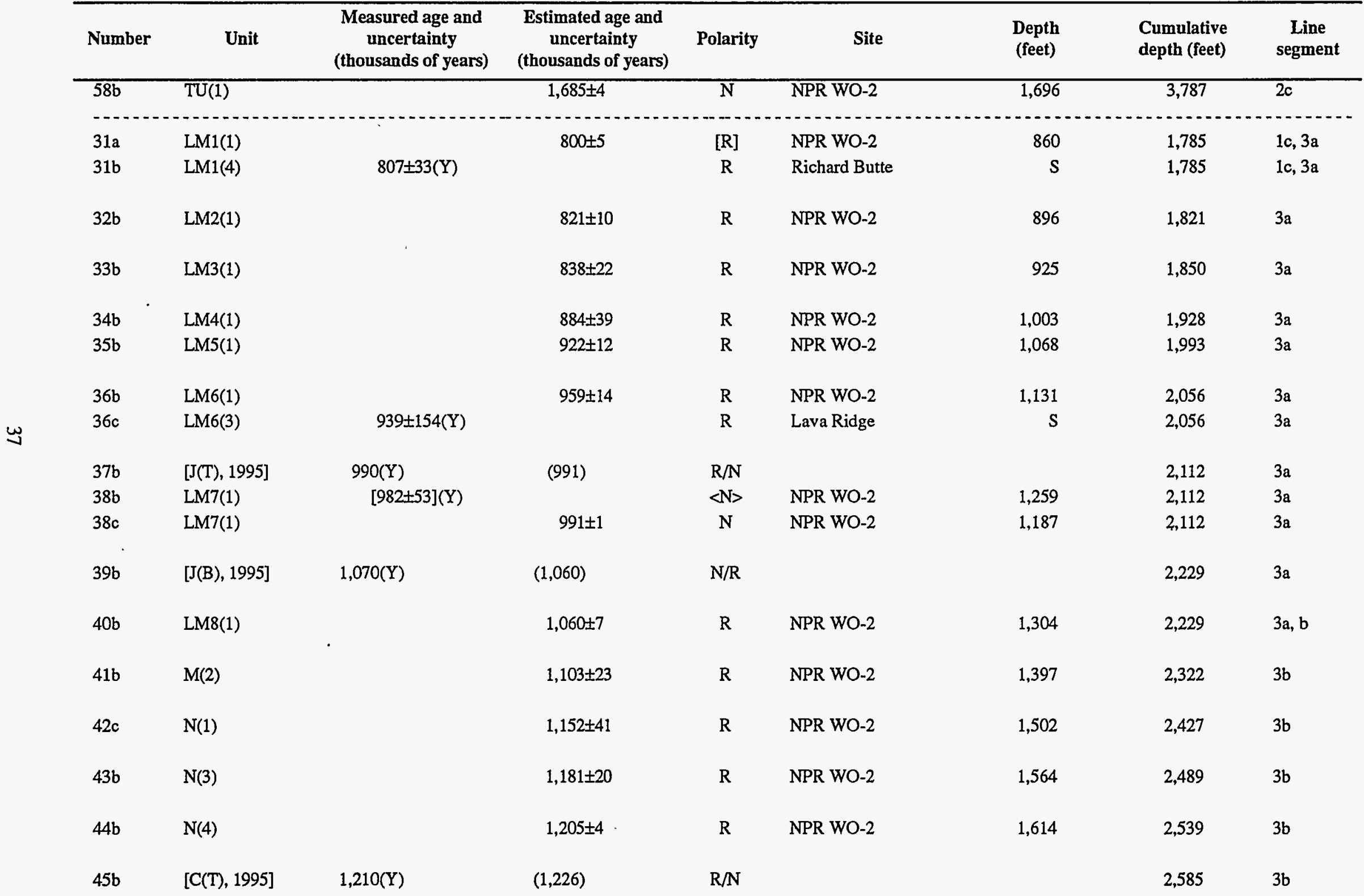


Table 6. Measured and estimated geologic ages of selected basalt-flow groups and sedimentary interbeds in the unsaturated zone and the Snake River Plain aquifer at the Idaho National Engineering Laboratory-Continued

\begin{tabular}{|c|c|c|c|c|c|c|c|c|}
\hline Number & Unit & $\begin{array}{l}\text { Measured age and } \\
\text { uncertainty } \\
\text { (thousands of years) }\end{array}$ & $\begin{array}{l}\text { Estimated age and } \\
\text { uncertainty } \\
\text { (thousands of years) }\end{array}$ & Polarity & Site & $\begin{array}{l}\text { Depth } \\
\text { (feet) }\end{array}$ & $\begin{array}{l}\text { Cumulative } \\
\text { depth (feet) }\end{array}$ & $\begin{array}{c}\text { Line } \\
\text { segment }\end{array}$ \\
\hline $46 \mathrm{~b}$ & $\mathrm{NO}(1)$ & & $1,226 \pm 11$ & $(\mathrm{~N})$ & NPR WO-2 & 1,660 & 2,585 & $3 b$ \\
\hline $46 \mathrm{~b}$ & $\mathrm{NO}(1)$ & & $1,226 \pm 11$ & $\mathrm{~N}$ & $\mathrm{C}-1 \mathrm{~A}$ & 1,074 & 2,585 & $3 b$ \\
\hline 47 & {$[\mathrm{C}(\mathrm{B}), 1995]$} & $1,240(\mathrm{~N})$ & -- & $N / R$ & & & -- & $3 b$ \\
\hline $48 \mathrm{~b}$ & $\mathrm{O}(1)$ & & $1,377 \pm 118$ & {$[\mathrm{R}]$} & $\mathrm{C}-1 \mathrm{~A}$ & 1,396 & 2,907 & $3 b$ \\
\hline $49 c$ & $\mathrm{P}(3)$ & & $1,415 \pm 117$ & $\mathrm{R}$ & $C-1 A$ & 1,477 & 2,988 & $3 b$ \\
\hline $49 c$ & $P(1)$ & & $1,415 \pm 117$ & $\mathrm{R}$ & $\mathrm{TCH} \# 2$ & 120 & 2,988 & $3 b$ \\
\hline $50 \mathrm{~b}$ & $\mathrm{Q}(1)$ & & $1,475 \pm 75$ & $\mathrm{R}$ & $\mathrm{TCH} \# 2$ & 246 & 3,114 & $3 b$ \\
\hline $51 \mathrm{c}$ & $\mathrm{R} 1(1)$ & & $1,572 \pm 6$ & $R$ & $\mathrm{TCH} \# 2$ & 453 & 3,321 & $3 b$ \\
\hline $51 \mathrm{~d}$ & R1(1) & $1,581 \pm 57(\mathrm{Y})$ & & $\mathrm{R}$ & $\mathrm{TCH} \# 1$ & 413 & 3,321 & $3 b$ \\
\hline \multirow[t]{2}{*}{$52 \mathrm{~b}$} & $\mathrm{R} 2(1)$ & & $1,581 \pm 0$ & $\mathrm{R}$ & $\mathrm{TCH} \# 2$ & 473 & 3,341 & $3 b$ \\
\hline & $\mathrm{R} 2(1)$ & $2,053 \pm 79(\mathrm{~N})$ & & $\mathrm{R}$ & $\mathrm{TCH} \# 2$ & 534 & 3,341 & \\
\hline \multirow[t]{2}{*}{$53 \mathrm{~b}$} & S1(1) & & $1,618 \pm 26$ & $\mathrm{R}$ & $\mathrm{TCH} \# 2$ & 551 & 3,419 & $3 b$ \\
\hline & $S 1(1)$ & $1,936 \pm 83(\mathrm{~N})$ & & $\mathrm{R}$ & $\mathrm{TCH} \# 1$ & 523 & 3,419 & \\
\hline \multirow[t]{2}{*}{$54 \mathrm{~b}$} & $S 2(1)$ & & $1,648 \pm 47$ & $\mathrm{R}$ & $\mathrm{TCH} \# 2$ & 615 & 3,483 & $3 b$ \\
\hline & S2(1) & $2,115 \pm 46(\mathrm{~N})$ & & $\mathrm{R}$ & $\mathrm{TCH} \# 2$ & 637 & 3,483 & \\
\hline \multirow[t]{2}{*}{$55 \mathrm{~b}$} & S5(1) & & $1,708 \pm 44$ & $\mathrm{R}$ & $\mathrm{TCH} \# 2$ & 743 & 3,611 & $3 b$ \\
\hline & S5(1) & $2,556 \pm 35(\mathrm{~N})$ & & $\mathrm{R}$ & $\mathrm{TCH} \# 2$ & 785 & 3,611 & \\
\hline \multicolumn{2}{|c|}{ Effective base of aquifer } & & & $\mathrm{R}$ & $\mathrm{TCH} \# 2$ & 883 & 3,751 & $3 b, c$ \\
\hline \multicolumn{2}{|c|}{ Effective base of aquifer } & & & $\mathrm{R}$ & NPR WO-2 & 1,660 & 3,751 & $3 b, c$ \\
\hline $56 \mathrm{~b}$ & {$[\mathrm{O}(\mathrm{T}), 1995]$} & $1,770(Y)$ & $(1,773)$ & $\mathrm{R} / \mathrm{N}$ & & & 3,751 & $3 b, c$ \\
\hline $57 \mathrm{~b}$ & $\mathrm{~T}(2)$ & & $1,773 \pm 2$ & {$[\mathrm{~N}]$} & NPR WO-2 & 1,660 & 3,751 & $3 b, c$ \\
\hline
\end{tabular}


Table 6. Measured and estimated geologic ages of selected basalt-flow groups and sedimentary interbeds in the unsaturated zone and the Snake River Plain aquifer at the Idaho National Engineering Laboratory-Continued

\begin{tabular}{|c|c|c|c|c|c|c|c|c|}
\hline Number & Unit & $\begin{array}{l}\text { Measured age and } \\
\text { uncertainty } \\
\text { (thousands of years) }\end{array}$ & $\begin{array}{l}\text { Estimated age and } \\
\text { uncertainty } \\
\text { (thousands of years) }\end{array}$ & Polarity & Site & $\begin{array}{l}\text { Depth } \\
\text { (feet) }\end{array}$ & $\begin{array}{l}\text { Cumulative } \\
\text { depth (feet) }\end{array}$ & $\begin{array}{c}\text { Line } \\
\text { segment }\end{array}$ \\
\hline $58 \mathrm{c}$ & TU(1) & & $1,790 \pm 14$ & $\bar{N}$ & NPR WO-2 & 1,696 & 3,787 & $3 c$ \\
\hline $58 \mathrm{~d}$ & TU(1) & $<1,865 \pm 24>(\mathrm{N})$ & & $N$ & NPR WO-2 & 1,708 & 3,787 & $3 c$ \\
\hline
\end{tabular}

